\title{
Rapid Discovery of Pyrido[3,4-d]pyrimidine Inhibitors of Monopolar Spindle Kinase 1 (MPS1) Using a Structure-Based Hybridization Approach
}

Paolo Innocenti, ${ }^{\dagger}$ Hannah L. Woodward, ${ }^{\dagger}$ Savade Solanki, ${ }^{\dagger}$ Sébastien Naud, ${ }^{\dagger}$ Isaac M. Westwood, ${ }^{\dagger,}$ Nora Cronin, ${ }^{\dagger}$ Angela Hayes, ${ }^{\dagger}$ Jennie Roberts, ${ }^{\dagger}$ Alan T. Henley, ${ }^{\dagger}$ Ross Baker, ${ }^{\dagger}$ Amir Faisal, ${ }^{\dagger, \|}$ Grace Wing-Yan Mak, ${ }^{\dagger}$ Gary Box, ${ }^{\dagger}$ Melanie Valenti, ${ }^{\dagger}$ Alexis De Haven Brandon, ${ }^{\dagger}$ Lisa O’Fee, ${ }^{\dagger}$ Harry Saville, ${ }^{\dagger}$ Jessica Schmitt, ${ }^{\dagger}$ Berry Matijssen, ${ }^{\dagger}$ Rosemary Burke, ${ }^{\dagger}$ Rob L. M. van Montfort, ${ }^{\dagger,}$ Florence I. Raynaud, ${ }^{\dagger}$ Suzanne A. Eccles, ${ }^{\dagger}$ Spiros Linardopoulos, ${ }^{\dagger, \S}$ Julian Blagg, $^{\dagger}$ and Swen Hoelder*, ${ }^{\dagger}$

Cancer Research UK Cancer Therapeutics Unit, Division of Cancer Therapeutics, The Institute of Cancer Research, 15 Cotswold Road, Sutton, London, SM2 5NG, United Kingdom

${ }^{*}$ Division of Structural Biology and ${ }^{\S}$ Breast Cancer Now, Division of Breast Cancer Research, The Institute of Cancer Research, 237 Fulham Road, London, SW3 6JB, United Kingdom

Supporting Information

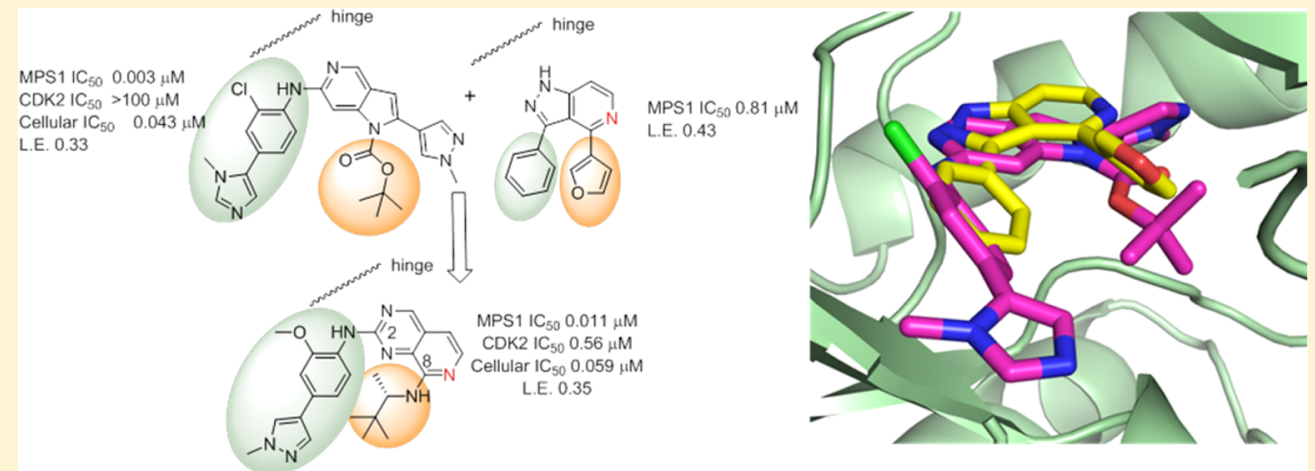

ABSTRACT: Monopolar spindle 1 (MPS1) plays a central role in the transition of cells from metaphase to anaphase and is one of the main components of the spindle assembly checkpoint. Chromosomally unstable cancer cells rely heavily on MPS1 to cope with the stress arising from abnormal numbers of chromosomes and centrosomes and are thus more sensitive to MPS1 inhibition than normal cells. We report the discovery and optimization of a series of new pyrido[3,4- $d]$ pyrimidine based inhibitors via a structure-based hybridization approach from our previously reported inhibitor CCT251455 and a modestly potent screening hit. Compounds in this novel series display excellent potency and selectivity for MPS1, which translates into biomarker modulation in an in vivo human tumor xenograft model.

\section{INTRODUCTION}

Interfering with mitotic processes has been a successful therapeutic approach to fight cancer. ${ }^{1}$ One example of a mitotic target is monopolar spindle 1 (MPS1, also known as TTK), a dual-specificity kinase that occupies a central role in the transition from metaphase to anaphase and is one of the main components of the spindle assembly checkpoint (SAC). ${ }^{2}$ This kinase prevents cells from progressing through mitosis until the kinetochores are properly attached to the microtubules and are under the appropriate tension. While this mechanism is important to ensure error-free segregation of chromosomes in normal tissues, aneuploid and chromosomally unstable cancer cells often overexpress, and are particularly dependent on, MPS1 to cope with the stress arising from abnormal numbers of chromosomes and centrosomes. ${ }^{3}$ Due to these findings, it is not surprising that MPS1 is upregulated in a number of tumor types ${ }^{4}$ and that higher levels correlate with higher histological grade, aggressiveness, and poorer patient survival in breast cancer, glioblastoma, and pancreatic ductal adenocarcinoma. ${ }^{4 a, 5}$ Furthermore, phosphatase and tensin homologue (PTEN)-deficient breast cancer cell lines have been reported to be more sensitive to MPS1 depletion or kinase inhibition. ${ }^{3 \mathrm{~b}, 6}$

Using advanced inhibitors, including our own 1 (CCT251455, vide infra), ${ }^{7}$ effective dosing schedules have been investigated in vivo. Importantly, it has recently been shown that MPS1 inhibitors have a relatively narrow therapeutic window ${ }^{5 a, 8}$ and that they are particularly effective when used in combination

Received: November 20, 2015

Published: April 7, 2016 
<smiles>Cn1cc(-c2cc3cnc(Nc4ccc(-c5cncn5C)c(Cl)c4)cc3n2C(=O)OC(C)(C)C)cn1</smiles>

ССT251455 1<smiles>COc1cc(N2CCC(O)CC2)ccc1Nc1nc(Nc2ccccc2OC(C)C)c2nc[nH]c2n1</smiles>

MPS-IN-3 5<smiles>COc1cc(OC2CCN(C)CC2)ccc1Nc1ncc2c(n1)n(C1CCCC1)c(=O)n2C</smiles>

AZ3146 2<smiles>Cc1cc(N2CCOCC2)ccc1Nc1nc(NC2CCCCC2)c2nc[nH]c2n1</smiles>

MPI-0479605 3<smiles>O=C(NC(c1ccccn1)C1CC1)c1ccc2[nH]nc(-c3ccc(N4CCC(O)CC4)cc3)c2c1</smiles>

CFI-401870 6

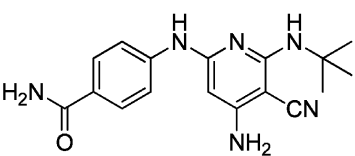

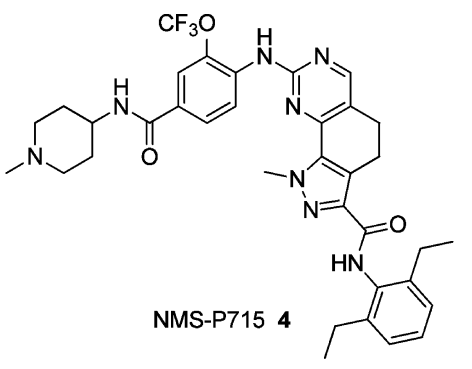

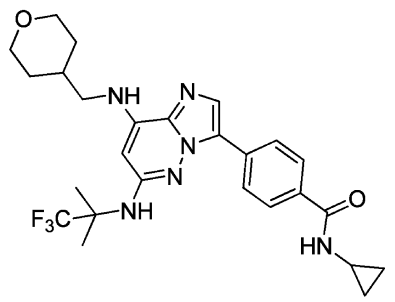

Figure 1. Published MPS1 inhibitors.

Scheme 1. Synthesis of Isoquinoline Derivatives ${ }^{a}$<smiles>Clc1cc2c(Br)cccc2cn1</smiles><smiles>[CH]C</smiles>

a)

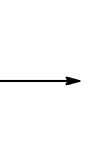

$\mathrm{R}^{1}=2$-furanyl $10 \quad(75 \%)$

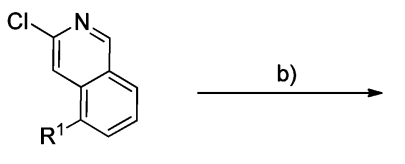

$=1$-methyl-1H-pyrazol-4-yl 11 (quant.)

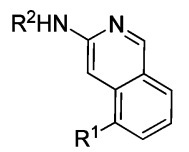

$\mathrm{R}^{1}=$ 2-furanyl, $\mathrm{R}^{2}=4$-methoxyphenyl $14 \quad(18 \%)$

$\mathrm{R}^{1}=1$-methyl-1H-pyrazol-4-yl, $\mathrm{R}^{2}=4$-methoxyphenyl 15a (8\%)

$\mathrm{R}^{1}=1$-methyl-1H-pyrazol-4-yl, $\mathrm{R}^{2}=2,4$-dimethoxyphenyl 15b $(27 \%)$

${ }^{a}$ Reagents and conditions: (a) Furan-2-ylboronic acid or 1-methyl-4-(4,4,5,5-tetramethyl-1,3,2-dioxaborolan-2-yl)-1 $1 \mathrm{H}_{\text {-pyrazole, }} \mathrm{Na}_{2} \mathrm{CO}_{3}$, $\mathrm{Pd}(\mathrm{dppf}) \mathrm{Cl}_{2} \cdot \mathrm{CH}_{2} \mathrm{Cl}_{2}, \mathrm{DME} /$ water, $\mu \mathrm{W}, 105{ }^{\circ} \mathrm{C}$; (b) 4-methoxyaniline 12 or 2,4-dimethoxyaniline 13, ${ }^{t} \mathrm{BuXPhos} \mathrm{Pd}_{2} \mathrm{dba}_{3}, \mathrm{Cs}_{2} \mathrm{CO}_{3},{ }^{t} \mathrm{BuOH} /$ water, $\mu \mathrm{W}, 80-100{ }^{\circ} \mathrm{C}$. Reaction yields are in parentheses.

with, for example, tubulin-targeting agents such as paclitaxel or CDK4/6 inhibitors. ${ }^{9}$

Several MPS1 inhibitors have been disclosed, ${ }^{10}$ these include AstraZeneca's AZ3146 (2), ${ }^{10 \mathrm{~b}}$ the Myrexis compound MPI0479605 (3), ${ }^{8 c}$ and the Nerviano compound NMS-P715 (4). ${ }^{11}$ Also described in the literature are MPS-IN-3 (5), ${ }^{5 a}$ CFI-401870 (6), ${ }^{12}$ and the Shionogi compounds $(7,8)$ (Figure 1). ${ }^{8 a, 13}$

We recently disclosed a series of $1 H$-pyrrolo[3,2-c]pyridines exemplified by the potent and selective chemical probe $\mathbf{1}^{7}$ However, while this compound showed excellent potency in biochemical and cellular assays, other properties hampered further development. In particular, 1 has a relatively high molecular weight (504) and AlogP (5.7) and also featured a tertbutoxycarbonyl (Boc) moiety that appeared critical for potent inhibition but unsurprisingly proved to be unstable under strongly acidic conditions. ${ }^{14}$ In addition, 1 was a potent cytochrome P450 (CYP) inhibitor $\left(\mathrm{IC}_{50}<1 \mu \mathrm{M}\right.$ observed for CYP 1A2, 3A4, 2C9, 2C19, 2D6) which represented a significant issue not least because MPS1 inhibitors are reported to be particularly effective in combination with other chemotherapeutic agents, e.g., paclitaxel. To mitigate the risk that these undesirable features were inherent to the $1 H$-pyrrolo[3,2c]pyridine series, we set out to discover a second structurally unrelated chemotype featuring a clean CYP profile, no acid labile groups, and significantly lower molecular weight and lipophilicity. We thus set out to discover an additional lead series that (a) showed potent inhibition of MPS1 in cellular assays $\left(\mathrm{IC}_{50}<100 \mathrm{nM}\right.$ ), (b) showed good ligand efficiency (L.E. $0.35),{ }^{15}$ (c) displayed excellent selectivity, in particular against other cell cycle kinases such as cyclin-dependent kinase 2 $(\mathrm{CDK} 2)$, Aurora $\mathrm{A}$ and $\mathrm{B}$, and more generally against the wider kinome $\left(K_{\mathrm{i}}\right.$ ratio $\left.>100\right),(\mathrm{d})$ robustly modulated MPS1 kinase activity in a human tumor xenograft PK/PD model, and (e) showed significant scope for further modification.

Herein we describe the rapid discovery of such a series by structure-based hybridization of the $1 \mathrm{H}$-pyrrolo[3,2-c]pyridine series and a modestly potent hit from a focused kinase library screen. This completely new MPS1 series featured an unexploited kinase chemotype (the pyrido[3,4-d]pyrimidines) and advanced examples displayed subnanomolar $K_{\mathrm{i}} \mathrm{s}$ and excellent overall selectivity. The favorable in vitro properties translated into biomarker modulation in an in vivo human tumor xenograft model.

\section{CHEMISTRY}

The synthesis of isoquinolines $14,15 a$ and $15 b$ was carried out from the commercially available 5-bromo-3-chloroisoquinoline 9 through sequential Suzuki couplings and Buchwald reactions using suitable boronic acids or esters and the required anilines (Scheme 1).

Compounds $\mathbf{2 4 a - d}$ and $\mathbf{2 8} \mathbf{a}-\mathbf{e}$ in the pyrido[3,4-d]pyrimidine series were prepared according to a previously described strategy which makes use of the novel 8-chloro-2(methylthio)pyrido $[3,4-d]$ pyrimidine building block $16 .{ }^{16}$ Thus, reaction with 1-methyl-4-(4,4,5,5-tetramethyl-1,3,2-dioxaborolan-2-yl)-1H-pyrazole or cyclopropylboronic acid under Suzuki conditions yielded intermediates 17 and 18. These thiomethyl derivatives were in turn oxidized to the corresponding sulfones 
Scheme 2. Synthesis of Pyrido[3,4-d] pyrimidine Derivatives $^{a}$
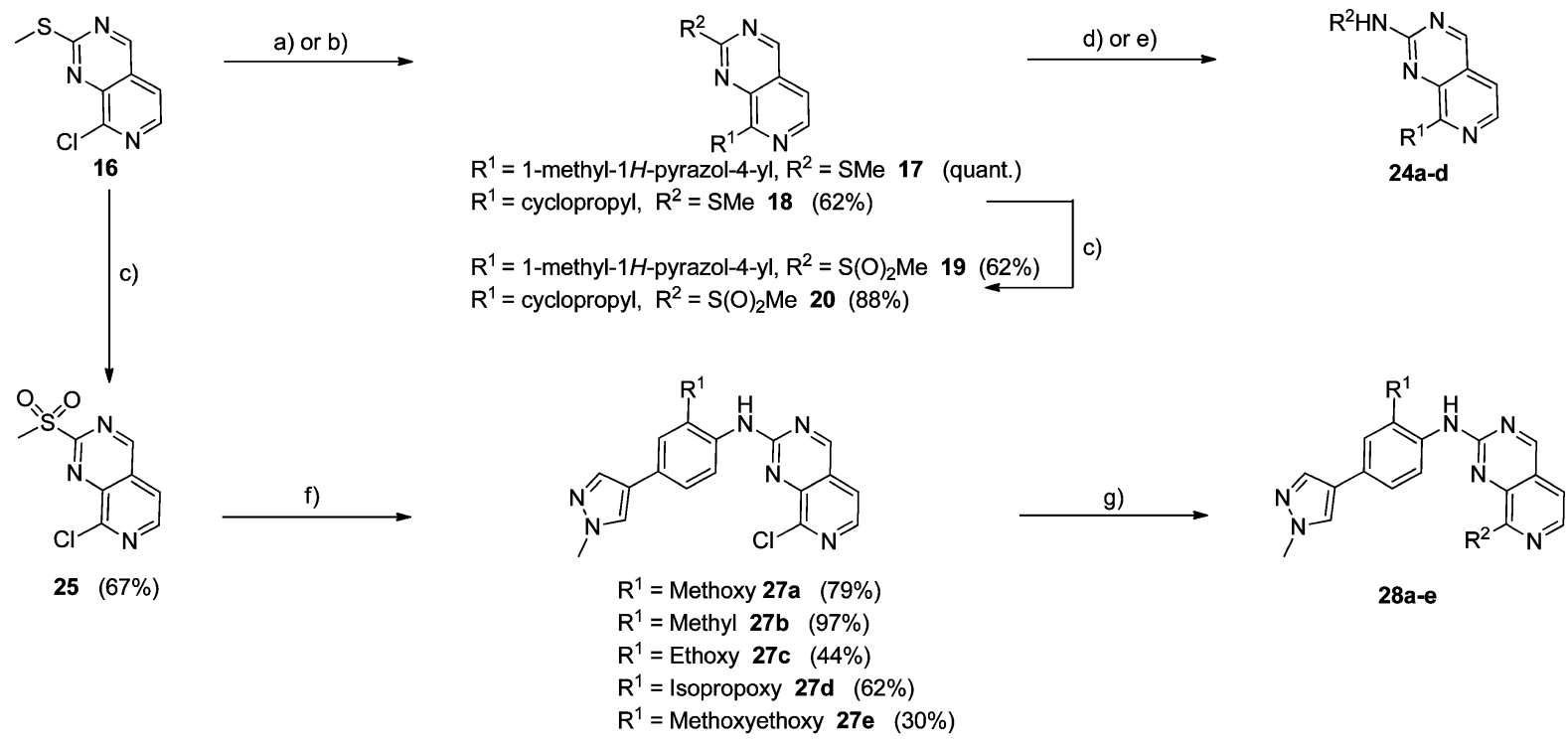

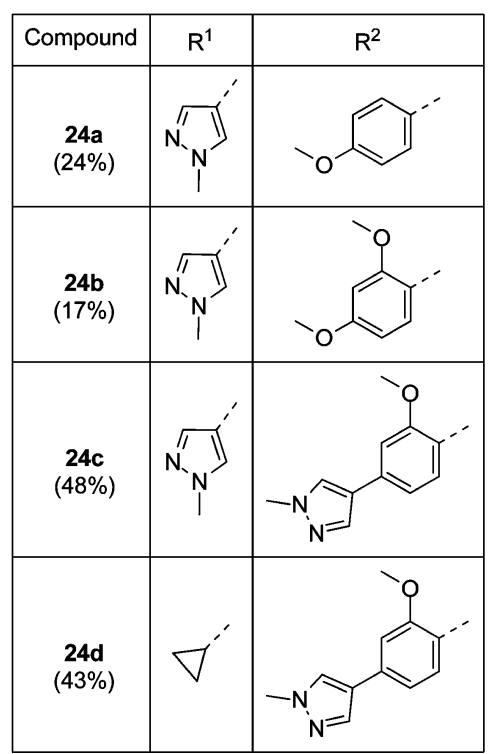

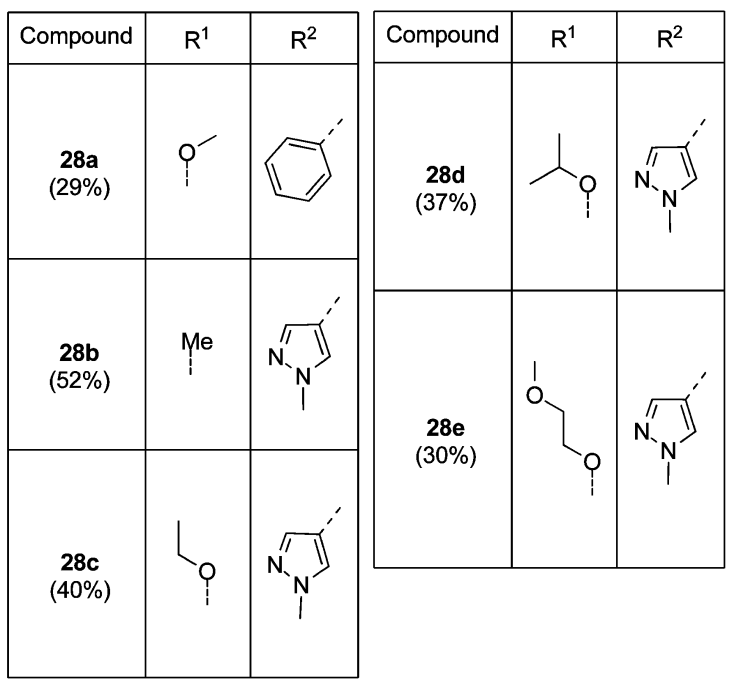

${ }^{a}$ Reagents and conditions: (a) 1-Methyl-4-(4,4,5,5-tetramethyl-1,3,2-dioxaborolan-2-yl)- $1 \mathrm{H}$-pyrazole, $\mathrm{Na}_{2} \mathrm{CO}_{3}, \mathrm{Pd}(\mathrm{dppf}) \mathrm{Cl}_{2} \cdot \mathrm{CH}_{2} \mathrm{Cl}_{2}, \mathrm{THF} /$ water, 65 ${ }^{\circ} \mathrm{C}$ (17); (b) cyclopropyl boronic acid, $\mathrm{K}_{3} \mathrm{PO}_{4}, \mathrm{Pd}(\mathrm{OAc})_{2}, \mathrm{PCy}_{3}$, toluene/water, $95{ }^{\circ} \mathrm{C}$ (18); (c) m-CPBA, $\mathrm{CH}_{2} \mathrm{Cl}{ }_{2}, \mathrm{rt}$; (d) $\mathrm{N}-(4-$ methoxyphenyl)formamide 21 or $\mathrm{N}$-(2,4-dimethoxyphenyl)formamide 22, DMSO, $\mathrm{Cs}_{2} \mathrm{CO}_{3}, 100{ }^{\circ} \mathrm{C}$ (24a,b); (e) 2-methoxy-4-(1-methyl-1Hpyrazol-4-yl)aniline 23, TFA, 1,2,3-trifluoroethanol, $\mu \mathrm{W}$, $130{ }^{\circ} \mathrm{C}(\mathbf{2 4 c , d})$; (f) ArNHCHO (26a-e), NaH, THF, rt; (g) 1-methyl-4-(4,4,5,5tetramethyl-1,3,2-dioxaborolan-2-yl)- $1 \mathrm{H}$-pyrazole or phenyl boronic acid, $\mathrm{Cs}_{2} \mathrm{CO}_{3}, \mathrm{Pd}\left(\mathrm{PPh}_{3}\right)_{4}, 1,4$-dioxane/water, $100{ }^{\circ} \mathrm{C}$. Reaction yields are in parentheses.

using $m$-CPBA and subsequently coupled with the required anilines or formamides to afford compounds $\mathbf{2 4 a}-\mathbf{d}$ (Scheme 2). In the majority of cases though, the order of events was reversed. Oxidation of 8-chloro-2-(methylthio)pyrido[3,4-d]pyrimidine 16 yielded the corresponding sulfone $25,{ }^{16}$ which was coupled with a series of formamides furnishing chloro-intermediates $\mathbf{2 7 a}-\mathbf{e}$ (Scheme 2). Final compounds $\mathbf{2 8 a}-\mathbf{e}$ were obtained by means of palladium-catalyzed Suzuki couplings with commercially available boronic acids or esters. Pyrido $[3,4-d]$ pyrimidines $33 \mathbf{a}$ and $\mathbf{3 3} \mathbf{b}$ were prepared by direct substitution of amines on the 8-chloro-2-(methylthio)pyrido[3,4-d]pyrimidine building block 16 (Scheme 3). The resulting thiomethyl derivatives 29 and 30 were oxidized to the corresponding sulfones 31 and 32 and subsequently coupled with the required formamides to afford final compounds $33 \mathbf{a}$ and $33 \mathbf{b}$.

Pyrido $[3,4-d]$ pyrimidines $34 \mathbf{a}-\mathbf{h}$ were prepared from intermediate $27 \mathrm{a}^{16}$ by displacement using the appropriate nucleophiles (Scheme 4). In one instance the synthetic strategy involved the use of known pyridone $35^{16}$ as a starting material: O-alkylation in the presence of base and bromomethyl cyclopropane gave intermediate 36 . Oxidation using $m$-CPBA and subsequent coupling with formamide $26 a^{16}$ afforded pyrido $[3,4-d]$ pyrimidine 38 (Scheme 4).

In all cases, formamides and anilines were commercially available $(12,13,21)$ or could be synthesized by means of standard transformations $\left(\mathbf{2 2}, \mathbf{2 3},{ }^{17}\right.$ and $\mathbf{2 6 a - e}$, see Exper- 
Scheme 3. Functionalization of Pyrido $[3,4-d]$ pyrimidine Core $^{a}$
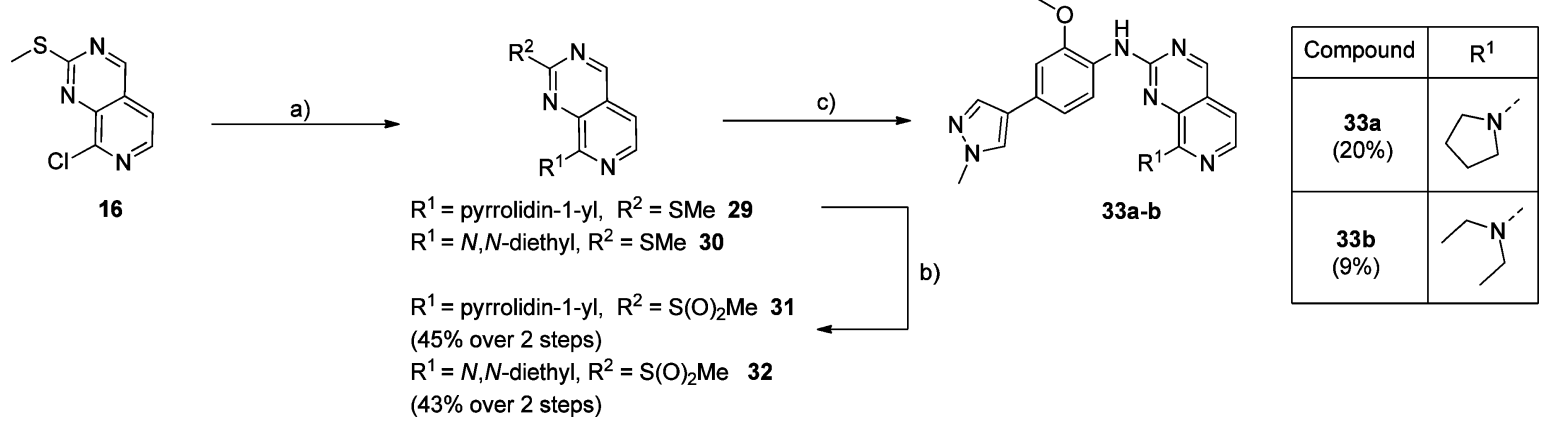

$43 \%$ over 2 steps)

${ }^{a}$ Reagents and conditions: (a) Amine, NMP, $80-135{ }^{\circ} \mathrm{C}$; (b) $m$-CPBA, $\mathrm{CH}_{2} \mathrm{Cl}_{2}$, rt; (c) 2-methoxy-4-(1-methyl-1H-pyrazol-4-yl)aniline 23, TFA, 1,2,3-trifluoroethanol, $\mu \mathrm{W}, 130{ }^{\circ} \mathrm{C}$. Reaction yields are in parentheses.

Scheme 4. Synthesis of Derivatives Containing 8-Position N, O, and S Substituents ${ }^{a}$
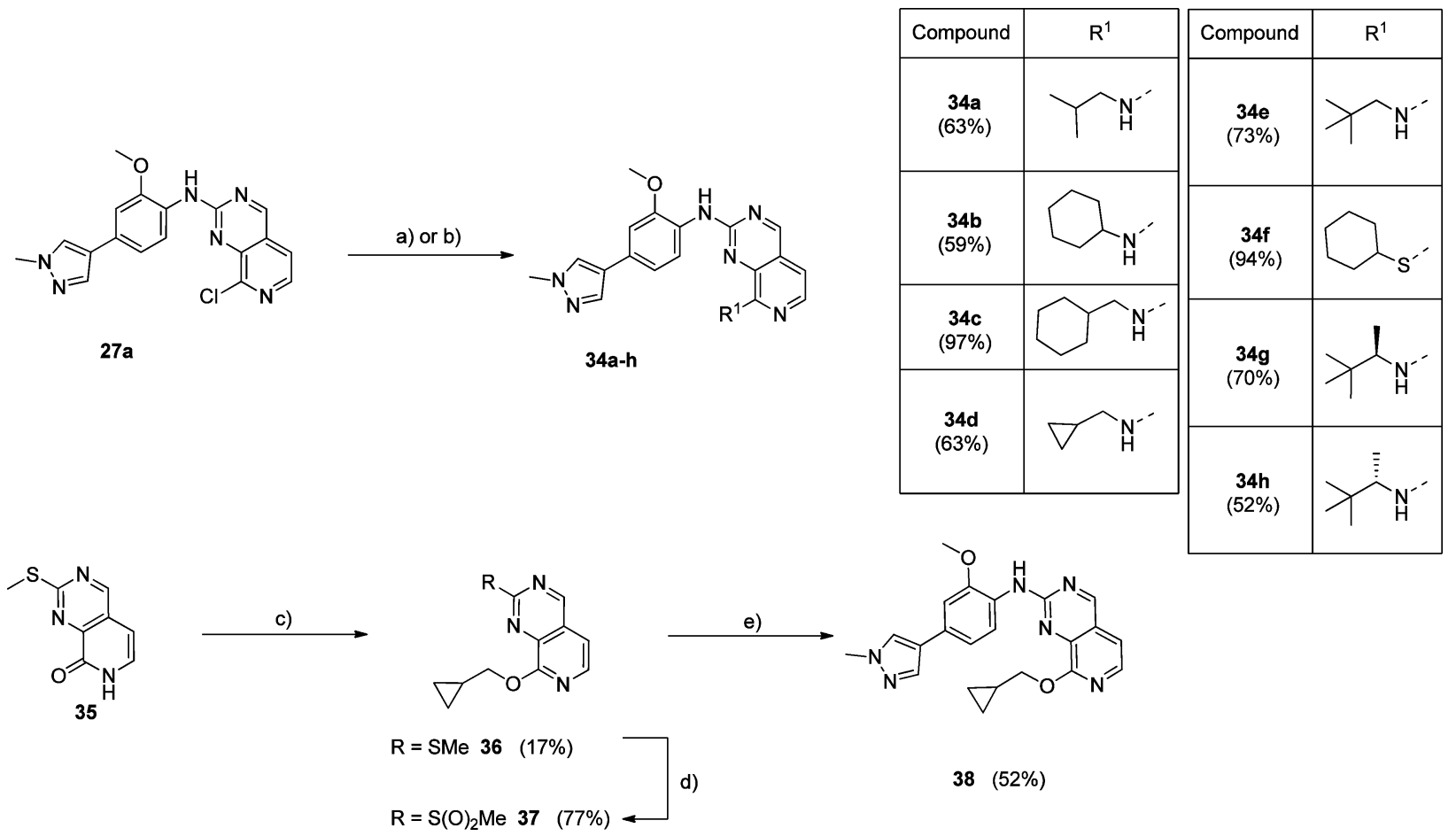

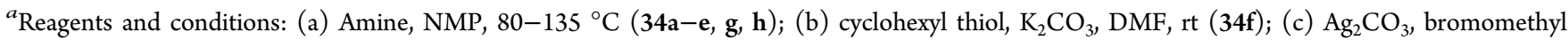
cyclopropane, $\mathrm{CHCl}_{3}$, rt to $60^{\circ} \mathrm{C}$; (d) $m$-CPBA, $\mathrm{CH}_{2} \mathrm{Cl}_{2}$, rt; (e) $N$-(2-methoxy-4-(1-methyl-1H-pyrazol-4-yl)phenyl)formamide 26a, NaH, THF, rt. Reaction yields are in parentheses.

imental section and Supporting Information for details). In every case, formylation was carried out by refluxing in formic acid.

\section{RESULTS AND DISCUSSION}

At the start of this work, relatively few inhibitors of MPS1 had been disclosed. In addition to our $1 H$-pyrrolo[3,2-c]pyridine series, $^{7}$ we had identified and crystallized $1 H$-pyrazolo[4,3c]pyridine 39, a modestly potent hit, during an initial screening campaign. This compound showed low molecular weight (MW = 261) and acceptable ligand efficiency (L.E. $=0.43)$. The crystal structure of MPS1 in complex with 39 revealed that it binds in a complementary way to 4 , whereby the pyrazole moiety binds to the hinge region of the protein. The furan moiety occupies the same region as the carbamate in the $1 \mathrm{H}$-pyrrolo[3,2-c] pyridine series. The phenyl ring and aniline moiety also occupy similar parts of the binding pocket (Figure 2). ${ }^{18}$ Based on these results, we anticipated that 39 would represent a viable starting point for a second series but that extensive optimization of potency and selectivity would be required. In order to rapidly discover a new series, while utilizing previously gained SAR data, we merged the $1 H$-pyrrolo[3,2-c]pyridine scaffold with the screening hit 39 (Figure 3). Docking suggested that both the isoquinoline and pyrido $[3,4-d]$ pyrimidine scaffolds could serve as hinge-binder elements for such a hybrid series (Figure 3). The isoquinoline scaffold had the advantage that proof-of-concept molecules could be rapidly prepared using precedented chemistry and commercially available building blocks. The pyrido[3,4- $d]$ pyrimidine scaffold, on the other hand, was attractive from the point of view of novelty, the significantly lower lipophilicity, and the fact that it incorporated an additional pyridine nitrogen from screening hit 39. This scaffold, however, required significant investigation into its synthesis. ${ }^{16}$ Our plan was thus to prepare a select number of 


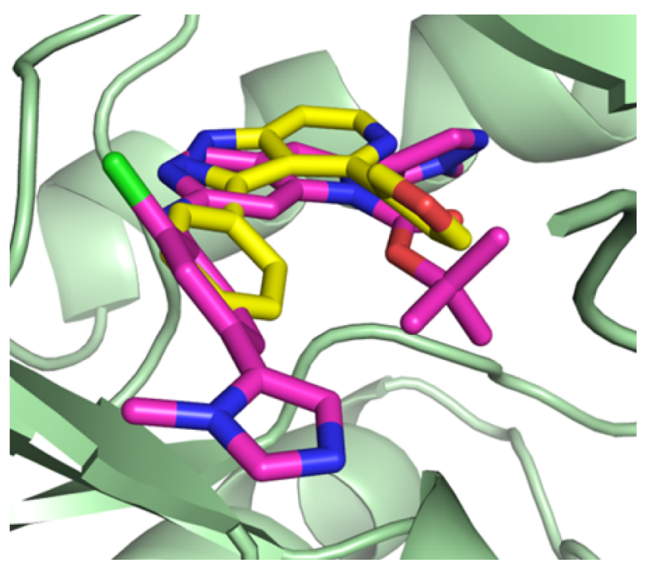

Figure 2. Superimposed crystal structure of MPS1 (pale green) bound to $\mathbf{1}$ (carbon atoms colored pink), extracted from PDB code 4C4J, onto the structure of MPS1 (not shown) bound to 39 (carbon atoms colored yellow), PDB code 5EHY, showing the complementary binding of the modestly potent hit 39 and MPS1 inhibitor 1 to the hinge region of MPS1.

proof-of-concept molecules based on the isoquinoline core and to expand into the less explored and more polar pyrido[3,4d] pyrimidine series if the initial isoquinolines showed promising activity and ligand efficiency.

We used our biochemical MPS1 assay at $10 \mu \mathrm{M}$ ATP concentration and an in-house electrochemiluminescence Meso Scale Discovery (MSD)-based cellular assay that measured autophosphorylation of ectopically expressed MPS1 in HCT116 cells. In addition, we routinely determined selectivity against $\mathrm{CDK} 2$ and Aurora A and B. We did not detect significant activity against either Aurora A or B throughout the series (see Supporting Information). Furthermore, as the $\mathrm{IC}_{50}$ values of our inhibitors approached the assay enzyme concentrations, and thus the limit of the dynamic range of our biochemical assay, we also determined the biochemical potency at a higher $(1 \mathrm{mM})$ ATP concentration (vide infra). As stated above, our overall goal for this lead-finding effort was to show that potent (cellular $\mathrm{IC}_{50}$ $<100 \mathrm{nM}$ ) and selective compounds (CDK2/MPS1 $K_{\mathrm{i}}$ ratio $>100$ ) could be obtained which exhibit lower molecular weight (around $450 \mathrm{Da}$ ) and improved ligand efficiency (L.E. in region of 0.35$)$ compared with the $1 H$-pyrrolo[3,2-c]pyridine series. Moreover, our goal was to show robust activity in our PK/PD human tumor xenograft model.
The data for the initial set of compounds are summarized in Table 1. The MPS1 inhibition for $\mathbf{1 4}$ was modest $\left(\mathrm{IC}_{50}=3.66\right.$ $\mu \mathrm{M}$, Table 1), but replacing the furan with a pyrazole (15a) not only lowered lipophilicity but also gave a 5-fold increase in potency (Table 1). Moreover, incorporating an additional methoxy group led to a significant gain in potency, and the $\mathrm{IC}_{50}$ of $\mathbf{1 5 b}$ reached our goal for an initial proof-of-concept compound. As seen with the $1 H$-pyrrolo[3,2-c]pyridines, ${ }^{7}$ the latter greatly improved selectivity toward CDK2. The significant gain in potency can be ascribed to the interaction of the aniline's 2-methoxy substituent with a small hydrophobic pocket formed by Lys529, Ile531, Gln541, and Cys604. This pocket is not present in most other kinases including CDK2, explaining the beneficial effect on kinase selectivity.

Having achieved satisfactory potency and ligand efficiency (L.E. for $15 \mathbf{b}=0.36$ ) by merging the $1 H$-pyrrolo[3,2-c]pyridine series and screening hit 39, we investigated the less lipophilic pyrido $[3,4-d]$ pyrimidine scaffold. Gratifyingly, 8-substituted 2anilinopyrido $[3,4-d]$ pyrimidines proved to be more potent than their isoquinoline counterparts, reaching the double digit nanomolar range despite significantly lower calculated $\log \mathrm{P}$ (Table 1). Isoquinoline $\mathbf{1 5 b}$ along with pyrido[3,4-d]pyrimidines 24a and 24b were next tested in an MSD-based cellular assay. Both $\mathbf{1 5 b}$ and $\mathbf{2 4 b}$ showed only modest inhibition of the autophosphorylation of ectopically expressed MPS1 in HCT116 cells, most likely due to suboptimal biochemical potency. In the $1 H$-pyrrolo[3,2-c] pyridine series, introduction of a pyrazole substituent at the 4-position of the aniline caused a significant increase in biochemical and cellular potency. ${ }^{7}$ Gratifyingly, this structural modification also resulted in a further improvement in biochemical potency for the pyrido[3,4d] pyrimidine series, with compound 24c achieving a MPS1 $\mathrm{IC}_{50}=0.008 \mu \mathrm{M}$ and a cellular P-MPS1 $\mathrm{IC}_{50}=0.604 \mu \mathrm{M}$ (Table $1)$.

We solved the crystal structure of MPS1 in complex with isoquinoline $\mathbf{1 5 b}$ and pyrido[3,4-d]pyrimidine $\mathbf{2 4 b}$ (Figure 4). The two structures overlaid very well with the crystal structure of 1 (Figure $4 \mathrm{~A}$ and $\mathrm{B}$ ), binding to the hinge region through the same motif as seen with the $1 H$-pyrrolo[3,2-c]pyridines. This reinforced our initial hypothesis that merging the $1 \mathrm{H}$-pyrrolo$[3,2-c]$ pyridine series and 39 would give a suitable starting point for an additional series of inhibitors. The aniline portion of all compounds overlaps as well as the 5-position and 8-position substituents of the isoquinolines and pyrido[3,4- $d]$ pyrimidines,

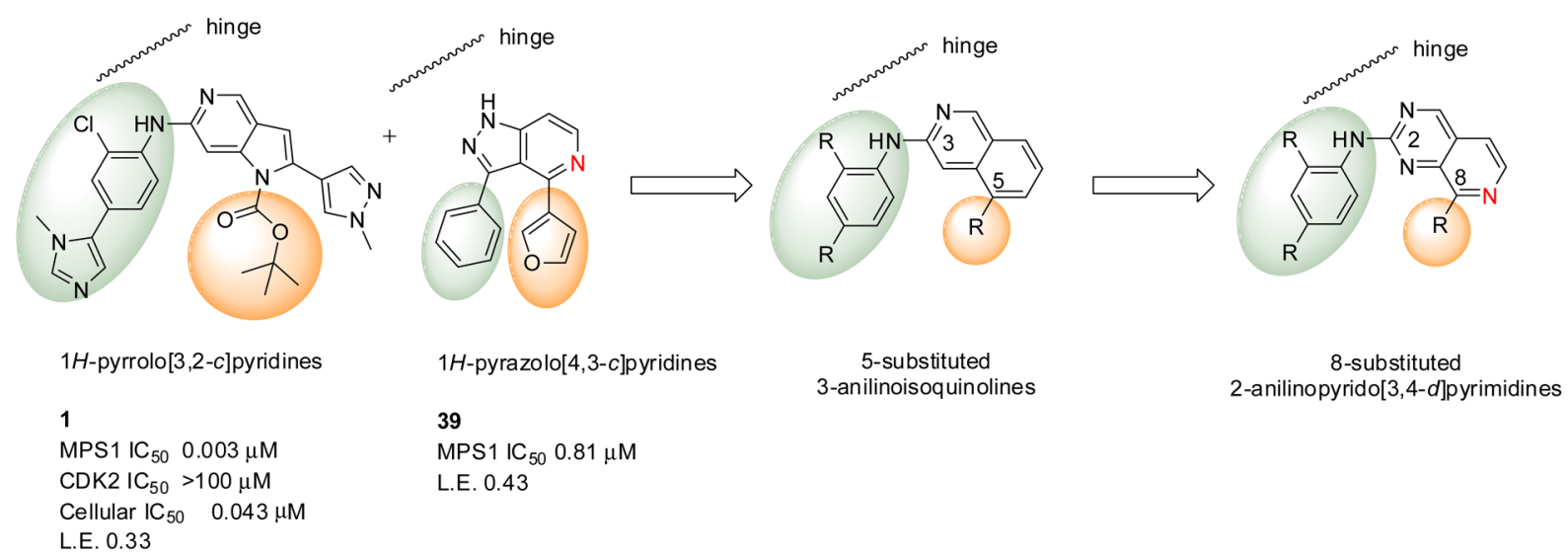

Figure 3. Hybridization strategy for the development of a novel chemical series of inhibitors of MPS1, from previously reported inhibitor 1 and screening hit 39. 
Table 1. Biochemical and Cellular Data for Initial Proof-of-Concept Isoquinolines (14, 15a, 15b) and Pyrido[3,4-d]pyrimidines $(24 a-c)^{a}$

\begin{tabular}{|c|c|c|c|c|c|}
\hline \multirow{2}{*}{ Compd } & \multirow{2}{*}{ Structure } & \multicolumn{2}{|c|}{ Biochemical $\operatorname{IC}_{50}(\mu \mathrm{M})$} & \multirow{2}{*}{$\begin{array}{c}\text { Cellular } \\
\text { P-MPS1 IC } \\
(\mu \mathrm{M}) \\
\end{array}$} & \multirow{2}{*}{$A \log P$} \\
\hline & & MPS1 & CDK2 & & \\
\hline 14 & & $\begin{array}{c}3.66 \\
(1.36,5.95)\end{array}$ & 31.1 & - & 4.57 \\
\hline $15 \mathrm{a}$ & & $0.66 \pm 0.08$ & $\begin{array}{c}1.22 \\
(1.54,0.91)\end{array}$ & - & 3.83 \\
\hline $15 b$ & & $0.099 \pm 0.064$ & 85.5 & $\begin{array}{c}2.77 \\
(1.93,3.61)\end{array}$ & 3.81 \\
\hline $24 a$ & & $0.14 \pm 0.05$ & $0.089 \pm 0.014$ & $>10$ & 2.89 \\
\hline $24 b$ & & $0.046 \pm 0.018$ & $1.54 \pm 0.30$ & $4.84 \pm 3.29$ & 2.87 \\
\hline $24 c$ & & $0.008 \pm 0.002^{\mathrm{b}}$ & $1.28 \pm 0.41$ & $0.60 \pm 0.16$ & 3.06 \\
\hline
\end{tabular}

${ }^{a}$ Results are mean $( \pm \mathrm{SD})$ for $n \geq 3$ or mean values of two independent determinations with individual determinations in parentheses or samples run $n=1$. "P-MPS1" indicates an electrochemiluminescence MSD-based cellular assay that measured autophosphorylation of ectopically expressed MPS1 in HCT116 cells. ${ }^{b}$ Potency at the lower limit of the dynamic range of the Caliper assay run at $10 \mu \mathrm{M}$ ATP concentration. IC ${ }_{50}$ value is likely to be lower than that quoted.

respectively, occupying the same region as the carbamate group of 1 . Of note is the difference in conformation for $\mathbf{1 5 b}$ and $\mathbf{2 4 b}$ (Figure 4C and D). The introduction of two extra nitrogen atoms into the aromatic ring, and thus removal of two hydrogen atoms, results in a much more planar structure for the pyrido[3,4d] pyrimidine $\mathbf{2 4 b}$. We measured the dihedral angles for both of these compounds: isoquinoline $\mathbf{1 5 b}$ exhibits a dihedral angle of $98^{\circ}$ and pyrido $[3,4-d]$ pyrimidine $24 \mathrm{~b}$ exhibits a dihedral angle of $-20^{\circ}$ (Figure 4D). The more coplanar conformation of pyrido $[3,4-d]$ pyrimidines mirrors the coplanar conformation of the carbamate function of $\mathbf{1}$ and is likely to be at least partially responsible for the improved activity seen with the much less lipophilic pyrido[3,4-d]pyrimidines. Based on these crystal structures, we had confidence that with further optimization we would achieve potent and selective pyrido $[3,4-d]$ pyrimidine based inhibitors of MPS1.

Through our hybridization strategy and exploration of the pyrido $[3,4-d]$ pyrimidine scaffold, we had achieved a potent inhibitor $\left(24 c\right.$, MPS1 $\left.\mathrm{IC}_{50}=0.008 \mu \mathrm{M}\right)$ and for the first time reached significant levels of cellular inhibition with $\mathrm{IC}_{50}$ values below $1 \mu \mathrm{M}$. Compound $24 \mathrm{c}$ represented a promising starting point for further optimization of this compound into a novel series of MPS1 inhibitors.
Since our initial goal was to show target modulation in a human tumor xenograft model in mice, we investigated the stability of $\mathbf{2 4 c}$ in mouse liver microsomes. Unfortunately, 24c showed high turnover ( $M L M=73 \%$ following $30 \mathrm{~min}$ incubation) and was not suitable for in vivo experiments. Metabolite ID studies suggested loss of a methyl group, and we suspected that the methoxy aniline substituent was the most likely site of demethylation. This methoxy group was important for both potency and selectivity. After consideration of the X-ray crystal structures we had in hand, suggesting that larger substituents at this position would be tolerated, we prepared and tested a series of compounds in which this putative metabolic soft spot was replaced with similar moieties (Table 2). The majority of these compounds showed higher $\mathrm{IC}_{50}$ values than $24 \mathrm{c}$ with the exception of the ethoxy derivative 28c, which achieved comparable potency, while exhibiting significantly improved CDK2 selectivity (>28 fold improvement over 24c) and MLM stability $(M L M=45 \%)$. This increase in selectivity is likely due to the fact that the aniline 2-position substituent occupies a small lipophilic pocket present in MPS1, mentioned previously, consisting of Lys529, Ile531, Gln541 and the gatekeeper+2 residue Cys604. This pocket is not available in CDK2 due to the presence of the bulkier gatekeeper residue Phe82. The larger 2- 

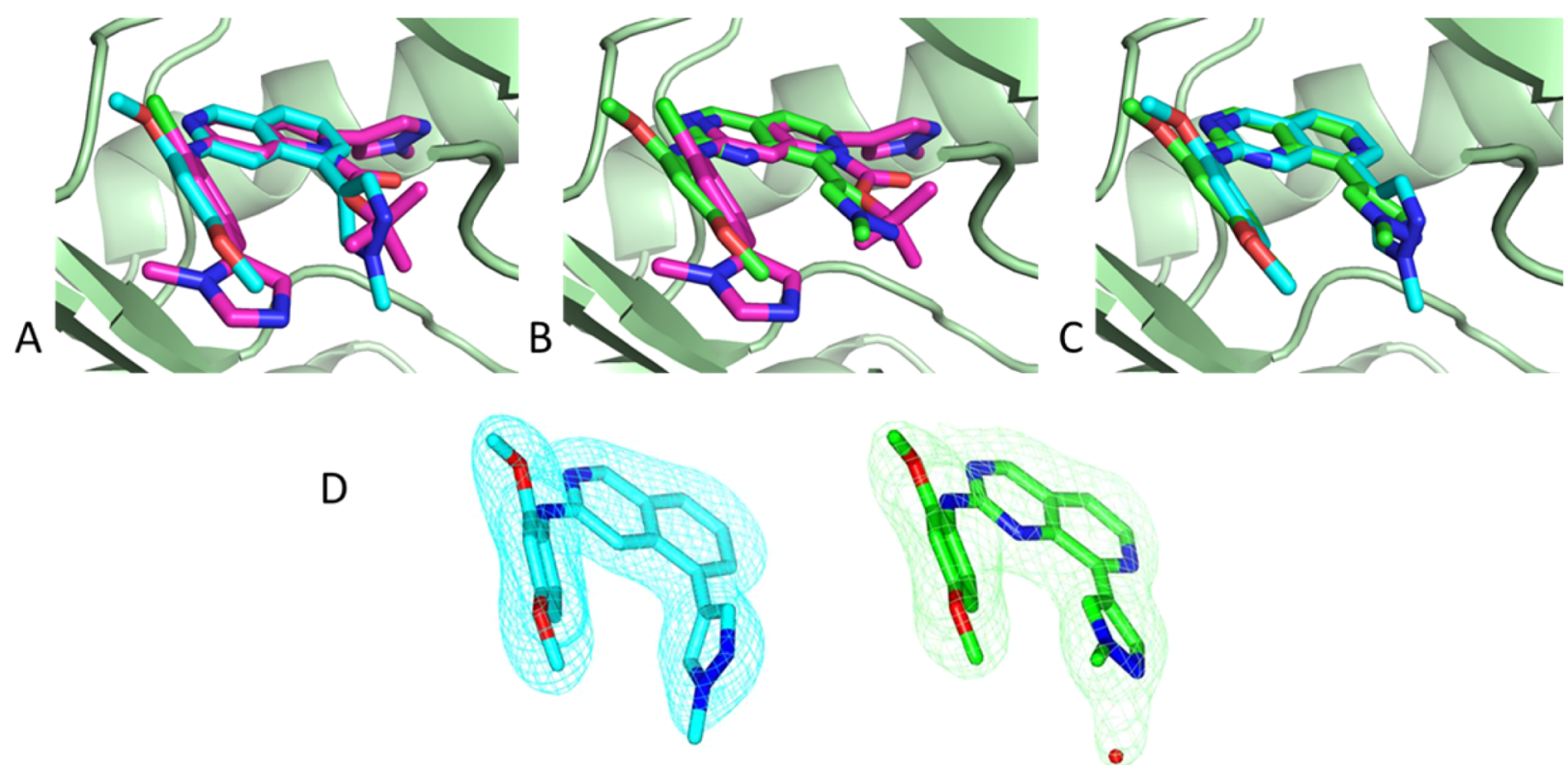

Figure 4. (A) Superimposed crystal structure of MPS1 (pale green) bound to 1 (carbon atoms colored pink), extracted from PDB code 4C4J, onto the structure of MPS1 (not shown) bound to 15b (carbon atoms colored cyan), PDB code 5EI6. (B) Superimposed crystal structure of MPS1 (pale green) bound to 1 (carbon atoms colored pink), extracted from PDB code 4C4J, onto the structure of MPS1 (not shown) bound to 24b (carbons atoms colored green), PDB code 5EI2. (C) Superimposed crystal structure of MPS1 (pale green) bound to 15b (carbon atoms colored cyan), extracted from PDB code 5EI6, onto the structure of MPS1 (not shown) bound to 24b (carbon atoms colored green), PDB code 5EI2, showing the extent of the conformational difference between the isoquinoline and pyrido[3,4-d]pyrimidine scaffolds. (D) Side-by-side view of compound $15 \mathbf{b}$ (carbon atoms colored cyan) and $\mathbf{2 4 b}$ (carbon atoms colored green) showing the difference in angle of the $N$-methylpyrazole group. $2 \mathrm{Fo}-\mathrm{Fc}$ density contoured at $1 \sigma$ is overlaid and displayed in the same color as the respective compound carbon atom color. A water molecule interacting with compound $\mathbf{2 4 \mathbf { b }}$ is also displayed as a red sphere. $\mathbf{1 5 b}$ exhibits a dihedral angle of $98^{\circ}$, and $24 \mathrm{~b}$ exhibits a dihedral angle of $-20^{\circ}$.

position ethoxy substituent (28c) clashes with the CDK2 gatekeeper +2 residue, resulting in a better selectivity window than is seen for the methoxy derivative $\mathbf{2 4 c}$.

Unfortunately, $\mathbf{2 8 c}$ was 5 -fold less active in the cellular assay, which given the similar biochemical potency and physicochemical properties was difficult to rationalize. While we regarded the ethoxy as a valuable alternative for the methoxy group, with significantly improved selectivity and reduced risk of reactive intermediate formation through metabolic dealkylation, we decided to maintain the methoxy in place due to the improved cellular activity. Instead, we looked to improve the metabolic stability through modification at the 8-position of the pyrido[3,4d]pyrimidine scaffold. We hypothesized that by introducing diverse substituents at this position of the scaffold, the molecular recognition of the compounds by metabolic enzymes would be affected leading to increased stability.

In order to address these aspects we used the structural information gathered on pyrido[3,4-d]pyrimidine $24 \mathrm{c}$. The crystal structure of this inhibitor showed that the 8-position pyrazole group binds to a hydrophobic pocket formed by Ile531, Val539, Met671, and Pro673 (Figure 5A). This is the same pocket that is occupied by the carbamate group of $\mathbf{1}$ and is sufficiently large to accommodate a variety of hydrophobic groups (Figure 5B). It is also of note that the crystal structure of MPS1 in complex with 24c shows ordering of the activation loop of MPS1, as is seen with 1 . $^{7}$ We thus prepared and tested a small set of compounds with different pyrazole replacements including a saturated pyrrolidine ring.

The data for these compounds are summarized in Table 3. The phenyl-substituted derivative (28a) showed comparable potency in the biochemical and cellular assay and, despite higher lipophilicity, improved microsomal stability. The cyclopropyl derivative $\mathbf{2 4 d}$ lost considerable activity, possibly due to the fact that this group is too small to engage in significant hydrophobic interactions. Interestingly, replacement of the pyrazole with a saturated pyrrolidine (33a) led to an equipotent compound in the biochemical assay. All compounds showed selectivity against CDK2 (CDK2/MPS1 ratio >80).

Of the compounds presented in Table 3, we considered the pyrrolidine derivative (33a) as the most promising for further optimization. A saturated moiety offered more possibilities to optimize the three-dimensional hydrophobic interactions in this subpocket compared with an aromatic ring where substituents can only be placed in the plane of the ring. Furthermore, increasing the number of $\mathrm{sp}^{3}$ centers has been suggested as a general approach to improve solubility and drug-like properties. ${ }^{19}$ We thus prepared a series of compounds with a saturated substituent in this position.

Importantly, since the $\mathrm{IC}_{50}$ values of many compounds were now approaching the enzyme concentration and thus the limit of the dynamic range of the biochemical assay, we complemented the MPS1 kinase assay at $10 \mu \mathrm{M}$ ATP with testing at $1 \mathrm{mM} \mathrm{ATP}$. It has been demonstrated that increasing the ATP concentration shifts the $\mathrm{IC}_{50}$ values of ATP competitive inhibitors to higher values, therefore increasing the dynamic range of the assay. ${ }^{20}$ Due to the differing ATP concentrations in the high ATP Caliper assay and the CDK2 assay ( $1 \mathrm{mM}$ MPS1 vs $10 \mu \mathrm{M}$ CDK2), the assays were no longer directly comparable. For this reason, we used the Cheng-Prusoff equation to calculate the $K_{\mathrm{i}}$ values ${ }^{21}$ and, in turn, used these values to determine the selectivity window.

Compound 33b, incorporating a diethylamine substituent, was significantly (6-fold) less potent in the $1 \mathrm{mM}$ ATP Caliper assay than the pyrrolidine 33a (Table 4). This is likely due to a 
Table 2. Biochemical, Cellular, And Mouse Microsomal Turnover Data for Compounds Bearing Alternative Aniline Substituents ${ }^{a}$<smiles>[R]c1ncc2ccnc(-c3cnn(C)c3)c2n1</smiles>

\begin{tabular}{|c|c|c|c|c|c|c|}
\hline \multirow{2}{*}{ Compd } & \multirow{2}{*}{$\mathbf{R}$} & \multicolumn{2}{|c|}{ Biochemical IC $_{50}(\mu \mathrm{M})$} & \multirow{2}{*}{$\begin{array}{r}\text { Cellular } \\
\text { P-MPS1 } \\
\text { IC }_{50}(\mu M) \\
\end{array}$} & \multirow{2}{*}{$\begin{array}{c}\text { MLM } \\
\% \\
\text { (30 } \mathrm{min}) \\
\end{array}$} & \multirow{2}{*}{$A \log P$} \\
\hline & & MPS1 & CDK2 & & & \\
\hline $24 \mathrm{c}$ & & $0.008 \pm 0.002^{\mathrm{b}}$ & $1.28 \pm 0.41$ & $0.60 \pm 0.16$ & 73 & 3.06 \\
\hline $28 b$ & & $0.024 \pm 0.014$ & $\begin{array}{c}0.38 \\
(0.17,0.59)\end{array}$ & $2.54 \pm 0.79$ & 63 & 3.56 \\
\hline $28 c$ & & $0.010 \pm 0.003^{\mathrm{b}}$ & $>45$ & $2.64 \pm 0.34$ & 45 & 3.41 \\
\hline 28d & & $\begin{array}{c}0.049 \\
(0.067,0.030)\end{array}$ & $>10$ & - & 45 & 3.78 \\
\hline $28 \mathrm{e}$ & & $0.14 \pm 0.05$ & - & - & 59 & 2.93 \\
\hline
\end{tabular}

${ }^{a}$ Results are mean $( \pm \mathrm{SD})$ for $n \geq 3$, or mean values of two independent determinations with individual determinations in parentheses or samples run $n=1$. "P-MPS1" indicates an electrochemiluminescence MSD-based cellular assay that measured autophosphorylation of ectopically expressed MPS1 in HCT116 cells. ${ }^{b}$ Potency at the lower limit of the dynamic range of the Caliper assay run at $10 \mu \mathrm{M}$ ATP concentration. IC s0 $_{5}$ value is likely to be lower than that quoted.

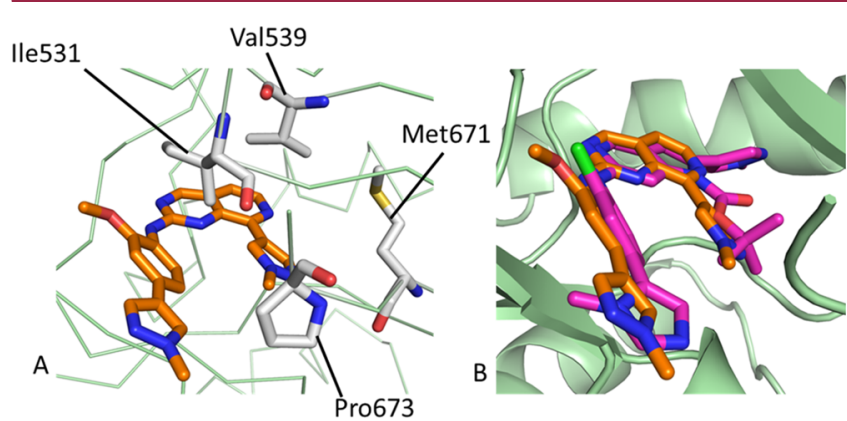

Figure 5. (A) Crystal structure of MPS1 (pale green) bound to 24c (carbon atoms colored orange), extracted from PDB code 5EI8, showing residues (Ile531, Val539, Met671, and Pro673) present in the hydrophobic pocket occupied by 8-position pyrazole. (B) Superimposed crystal structure of MPS1 (pale green) bound to $24 \mathrm{c}$ (carbon atoms colored orange), extracted from PDB code 5EI8, onto the structure of MPS1 (not shown) bound to $\mathbf{1}$ (carbon atoms colored pink), PDB code 4C4J, showing that this is the same pocket occupied by the carbamate group of $\mathbf{1}$ (carbon atoms colored pink).

higher free energy penalty when binding to the target for this less constrained compound. Gratifyingly, several amine substituents (34b, d, and e) not only showed comparable biochemical potency but also improved microsomal stability, now in an acceptable range of $30 \%$ turnover.

Since saturated amines were well tolerated in this position, we next prepared and tested derivatives in which the alkyl groups were linked through a sulfur or oxygen atom (34f and 38). Remarkably, both lost significant activity (at least 10-fold) compared to the corresponding amine derivatives $34 \mathrm{~b}$ and $\mathbf{3 4 d}$. It is difficult to reconcile the pronounced loss of activity of compounds $34 \mathrm{f}$ and 38 with the wide range of both primary and secondary amines that are tolerated. Computational conformational analysis did not suggest a significant difference in the conformational preference of the oxygen and sulfur-linked substituents compared to the amine substituents. Furthermore, analysis of the available crystal structure did not support the hypothesis that this difference may be driven by different hydrogen-bond pattern, e.g., to water molecules.

Several amino-substituted compounds did however show potent $\mathrm{IC}_{50}$ values suggesting significant scope for further modifications. The neopentyl derivative $34 \mathrm{e}$ was particularly promising due to its cellular potency combined with selectivity and improved mouse microsomal stability. As is apparent from the MPS1 $\mathrm{IC}_{50}$ at $1 \mathrm{mM} \mathrm{ATP}$, it was also the most potent derivative in this series. 
Table 3. Biochemical, Cellular, And Mouse Microsomal Turnover Data for Compounds Bearing Alternative 8-Position Substituents $^{a}$

\begin{tabular}{|c|c|c|c|c|c|c|}
\hline \multirow{2}{*}{ Compd } & \multirow{2}{*}{$\mathbf{R}$} & \multicolumn{2}{|c|}{ Biochemical $\mathrm{IC}_{50}(\mu \mathrm{M})$} & \multirow{2}{*}{$\begin{array}{c}\text { Cellular } \\
\text { P-MPS1 } \\
\text { IC }_{50}(\mu M) \\
\end{array}$} & \multirow{2}{*}{$\begin{array}{c}\text { MLM } \\
\% \\
(30 \mathrm{~min}) \\
\end{array}$} & \multirow{2}{*}{$A \log P$} \\
\hline & & MPS1 & CDK2 & & & \\
\hline $24 c$ & & $0.008 \pm 0.002^{\mathrm{b}}$ & $1.28 \pm 0.41$ & $0.60 \pm 0.16$ & 73 & 3.06 \\
\hline 28a & & $0.018 \pm 0.006$ & $>100$ & $0.48 \pm 0.10$ & 40 & 4.41 \\
\hline 24d & $\nabla^{\prime}$ & $0.11 \pm 0.02$ & $\begin{array}{c}9.74 \\
(12.55,6.93)\end{array}$ & $7.81 \pm 6.18$ & 51 & 3.50 \\
\hline 33a & $N^{\prime}$ & $0.010 \pm 0.003^{\mathrm{b}}$ & $2.83 \pm 0.77$ & $2.20 \pm 1.71$ & 64 & 3.62 \\
\hline
\end{tabular}

${ }^{a}$ Results are mean $( \pm \mathrm{SD})$ for $n \geq 3$, or mean values of two independent determinations with individual determinations in parentheses or samples run $n=1$. "P-MPS1" indicates an electrochemiluminescence MSD-based cellular assay that measured autophosphorylation of ectopically expressed MPS1 in HCT116 cells. ${ }^{b}$ Potency at the lower limit of the dynamic range of the Caliper assay run at $10 \mu \mathrm{M}$ ATP concentration. IC $\mathrm{C}_{50}$ value is likely to be lower than that quoted.

We solved the structure of neopentyl $34 \mathrm{e}$ bound into MPS1 (Figure 6). Figure 6 shows that the bulkier, more hydrophobic neopentyl substituent of $34 \mathrm{e}$ addresses the hydrophobic pocket first mentioned in Figure 5A to a greater extent than the pyrazole substituent of 24c. We hypothesized that an additional increase in potency could be achieved by further increasing the bulk of the hydrophobic substituent.

We thus followed up by synthesizing the two enantiomers $\mathbf{3 4 g}$ and $34 \mathrm{~h}$ which differ from the neopentyl $34 \mathrm{e}$ by an additional methyl group (Table 5). The $(S)$-enantiomer (34h) particularly, translated into an additional gain in biochemical and cellular potency compared with neopentyl derivative 34e, achieving cellular modulation of MPS1 in the sub- $100 \mathrm{nM}$ range (Table 5). 34h showed sufficient selectivity over CDK2 and very good microsomal stability (MLM $=27 \%$ ).

With $34 \mathrm{~h}$ we had achieved our initial potency goal in the biochemical and cellular assay. Especially considering its moderate molecular weight of $432 \mathrm{Da}, 34 \mathrm{~h}$ represented an extremely potent MPS 1 inhibitor with an $\mathrm{IC}_{50}=0.020 \mu \mathrm{M}$ at 1 mM ATP (corresponding to a $K_{\mathrm{i}}$ of $\left.0.0002 \mu \mathrm{M}\right)^{21}$ and a $\mathrm{GI}_{50}$ value in HCT 116 cells of $0.16 \mu \mathrm{M}$. Furthermore, the combined SAR suggested significant scope for additional modifications to further optimize the series. This pyrido $[3,4-d]$ pyrimidine $(34 \mathbf{h})$ was selective over CDK2 (CDK2/MPS1 $K_{\mathrm{i}}$ ratio > 1000), ${ }^{21}$ Aurora A and B (Table S1 ), and PLK1 $\left(\mathrm{IC}_{50}>100 \mu \mathrm{M}\right)$ as well as against a wide panel of kinases (Tables S2-S4 ). Pyrido[3,4d] pyrimidine $\mathbf{3 4 \mathrm { h }}$ inhibited a small number of kinases, namely TNK2, JNK1, JNK2, and LRRK at $>80 \%$ at $1 \mu \mathrm{M}$. JNK1 and JNK2 are considered to be structurally related to MPS1, so follow up $\mathrm{IC}_{50}$ values were obtained $\left(\mathrm{JNK} 1 \mathrm{IC}_{50}=0.11 \mu \mathrm{M}\right.$, JNK2 $\mathrm{IC}_{50}$
$=0.22 \mu \mathrm{M})$, showing that $34 \mathrm{~h}$ was selective for MPS1 over JNK1 and JNK2 by 100 - and 200-fold, respectively.

Next we profiled $34 \mathrm{~h}$ against a panel of cell lines (Table 6). As expected for an MPS1 inhibitor, 34h showed potent growth inhibition for all cancer cell lines but importantly a significantly higher $\mathrm{GI}_{50}$ for the nontransformed line PNT2.

34h did not inhibit CYP or hERG (Tables S5 and S6). Importantly, pyrido $[3,4-d]$ pyrimidine $34 \mathrm{~h}$, showed low turnover in mouse and rat liver microsomes (27 and $24 \%$, after $30 \mathrm{~min}$ incubation, respectively), and we progressed the compound to mouse and rat PK experiments, despite a 70\% turnover in human liver microsomes, in order to evaluate its suitability for proof of mechanism in vivo experiments. $34 \mathrm{~h}$ showed moderate clearance (28 and $24 \mathrm{~mL} / \mathrm{min} / \mathrm{kg}$ in mouse and rat, respectively) and high oral bioavailability (68 and 100\% in mouse and rat, respectively) with moderate to high volumes of distribution (Table 7).

We thus performed a 3 day pharmacokinetic/pharmacodynamic $(\mathrm{PK} / \mathrm{PD})$ study to determine whether biomarker modulation could be achieved in vivo. MPS1 inhibition results in premature exit of cells from mitosis, ${ }^{10 e}$ and we therefore chose the mitotic marker phospho-histone $\mathrm{H} 3$ as a readout. Histone $\mathrm{H} 3$ is specifically phosphorylated at Ser 10 during mitosis. ${ }^{22}$ Gratifyingly, oral administration of $100 \mathrm{mg} / \mathrm{kg}$ of $34 \mathrm{~h}$ b.i.d. for 3 days to mice bearing HCT116 human colon carcinoma xenografts caused a reduction of the phospho-histone $\mathrm{H} 3$ levels compared with vehicle control treated animals at 2 and $6 \mathrm{~h}$, consistent with MPS1 inhibition (Figure 7).

Compound $34 \mathrm{~h}$ fulfilled all of the criteria we had initially set and compared favorably with our best-in-class $1 H$-pyrrolo[3,2c]pyridine (1). Particularly, 34h was devoid of CYP inhibition, did not require an acid labile Boc group for biochemical and 
Table 4. Biochemical, Cellular, And Mouse Microsomal Turnover Data for Compounds Bearing a Saturated Substituent at the 8Position $^{a}$

\begin{tabular}{|c|c|c|c|c|c|c|c|c|c|c|}
\hline \multirow{3}{*}{ Compd } & \multirow{3}{*}{$\mathbf{R}$} & \multirow{3}{*}{$\begin{array}{c}\text { MPS1 } \\
\text { IC }_{50}\end{array}$} & \multicolumn{3}{|c|}{$\begin{array}{c}\begin{array}{c}\text { Biochemical activity } \\
(\mu \mathrm{M})\end{array} \\
\end{array}$} & & \multicolumn{2}{|c|}{$\begin{array}{c}\text { Cellular activity } \\
(\mu \mathrm{M})\end{array}$} & \multirow{3}{*}{$\begin{array}{c}\text { MLM } \\
\% \\
\mathbf{( 3 0} \\
\text { min) }\end{array}$} & \multirow{3}{*}{$\begin{array}{c}\text { AlogP } \\
/ \\
\text { L.E. }\end{array}$} \\
\hline & & & \multicolumn{2}{|c|}{$\begin{array}{c}\text { MPS1 } \\
\text { (1 mM ATP) } \\
\end{array}$} & \multicolumn{2}{|c|}{ CDK2 } & \multirow{2}{*}{$\begin{array}{c}\text { P-MPS1 } \\
\text { IC }_{50}\end{array}$} & \multirow{2}{*}{$\begin{array}{c}\text { HCT } \\
116 \\
\text { GI }_{50}\end{array}$} & & \\
\hline & & & IC $_{50}$ & $\mathbf{K}_{\mathbf{i}}$ & $\mathrm{IC}_{\mathbf{5 0}}$ & $\mathbf{K}_{\mathbf{i}}$ & & & & \\
\hline 33a & & $\begin{array}{c}0.010 \\
\pm \\
0.003^{\mathrm{b}}\end{array}$ & $\begin{array}{c}0.33 \\
\pm \\
0.18\end{array}$ & 0.0033 & $\begin{array}{c}2.83 \\
\pm \\
0.77\end{array}$ & 1.42 & $\begin{array}{c}2.20 \\
\pm \\
1.71\end{array}$ & $\begin{array}{r}0.47 \\
(0.46 \\
0.47)\end{array}$ & 64 & $\begin{array}{l}3.62 / \\
0.37\end{array}$ \\
\hline 33b & & $\begin{array}{c}0.062 \\
\pm \\
0.010\end{array}$ & $\begin{array}{c}>1 \\
(n=2)\end{array}$ & - & - & - & - & - & - & $\begin{array}{l}3.86 / \\
0.34\end{array}$ \\
\hline $34 a$ & & $\begin{array}{c}0.016 \\
\pm \\
0.008^{\mathrm{b}}\end{array}$ & $\begin{array}{c}0.37 \\
\pm \\
0.15\end{array}$ & 0.0037 & $\begin{array}{c}0.85 \\
\pm \\
0.40\end{array}$ & 0.43 & $\begin{array}{c}0.65 \\
\pm \\
0.17\end{array}$ & 1.1 & 66 & $\begin{array}{l}4.00 / \\
0.36\end{array}$ \\
\hline 34b & & $\begin{array}{c}0.012 \\
\pm \\
0.005^{b}\end{array}$ & $\begin{array}{c}0.13 \\
(0.18 \\
0.08)\end{array}$ & 0.0013 & $\begin{array}{c}0.19 \\
\pm \\
0.04\end{array}$ & 0.10 & $\begin{array}{c}0.22 \\
\pm \\
0.06\end{array}$ & $\begin{array}{c}0.12 \\
(0.10 \\
0.14)\end{array}$ & 22 & $\begin{array}{l}4.67 / \\
0.35\end{array}$ \\
\hline $34 \mathrm{c}$ & & $\begin{array}{c}0.046 \\
\pm \\
0.015\end{array}$ & $\begin{array}{c}>1 \\
(n=2)\end{array}$ & - & - & - & - & - & - & $\begin{array}{l}5.00 / \\
0.31\end{array}$ \\
\hline 34d & & $\begin{array}{c}0.011 \\
\pm \\
0.004^{\mathrm{b}}\end{array}$ & $\begin{array}{c}0.28 \\
\pm \\
0.16\end{array}$ & 0.0028 & $\begin{array}{c}1.08 \\
\pm \\
0.69\end{array}$ & 0.54 & $\begin{array}{c}0.43 \\
\pm \\
0.06\end{array}$ & 0.32 & 33 & $\begin{array}{l}3.63 / \\
0.37\end{array}$ \\
\hline $34 \mathrm{e}$ & & $\begin{array}{c}0.018 \\
\pm \\
0.017^{\mathrm{b}}\end{array}$ & $\begin{array}{c}0.045 \\
\pm \\
0.023\end{array}$ & 0.0005 & $\begin{array}{c}0.45 \\
\pm \\
0.21\end{array}$ & 0.23 & $\begin{array}{c}0.14 \\
(0.15 \\
0.14)\end{array}$ & $\begin{array}{c}0.34 \\
(0.24 \\
0.43)\end{array}$ & 31 & $\begin{array}{l}4.27 / \\
0.35\end{array}$ \\
\hline $34 f$ & & $\begin{array}{c}0.25 \\
\pm \\
0.13\end{array}$ & - & - & $\begin{array}{c}>10 \\
0\end{array}$ & - & - & - & - & $\begin{array}{l}5.40 / \\
0.29\end{array}$ \\
\hline 38 & & $\begin{array}{c}0.15 \\
(0.10 \\
0.20)\end{array}$ & - & - & - & - & - & - & - & $\begin{array}{l}3.80 / \\
0.32\end{array}$ \\
\hline
\end{tabular}

${ }^{a}$ Results are mean $( \pm \mathrm{SD})$ for $n \geq 3$, or mean values of two independent determinations with individual determinations in parentheses or samples run $n=1$. "P-MPS1" indicates an electrochemiluminescence MSD-based cellular assay that measured autophosphorylation of ectopically expressed MPS1 in HCT116 cells. "HCT116 GI $_{50}$ " indicates a cell proliferation assay carried out by colorimetric 3-(4,5-dimethylthiazol-2-yl)-2,5diphenyltetrazolium bromide (MTT) assay in HCT116 cells. ${ }^{b}$ Potency at the lower limit of the dynamic range of the Caliper assay run at $10 \mu \mathrm{M}$ ATP concentration. $\mathrm{IC}_{50}$ value is likely to be lower than that quoted.

cellular potency, and showed excellent overall selectivity. Its physicochemical properties $(\mathrm{ALog} P=4.65$ and $\mathrm{MW}=432)$ made $34 \mathrm{~h}$ a better starting point for further optimization especially given that we had already achieved the targeted potency. Surprisingly, given that it represented a pyrimidinebased kinase scaffold, the 2 -amino pyrido[3,4- $d]$ pyrimidine chemotype was relatively unexplored when we initiated this work, with only one published kinase patent application in the public domain. ${ }^{23}$ Our previously published chemical route ${ }^{16}$ facilitated the synthesis of a large range of derivatives as well as upscaling of advanced derivatives. We thus nominated $34 \mathrm{~h}$ as an advanced lead compound. 


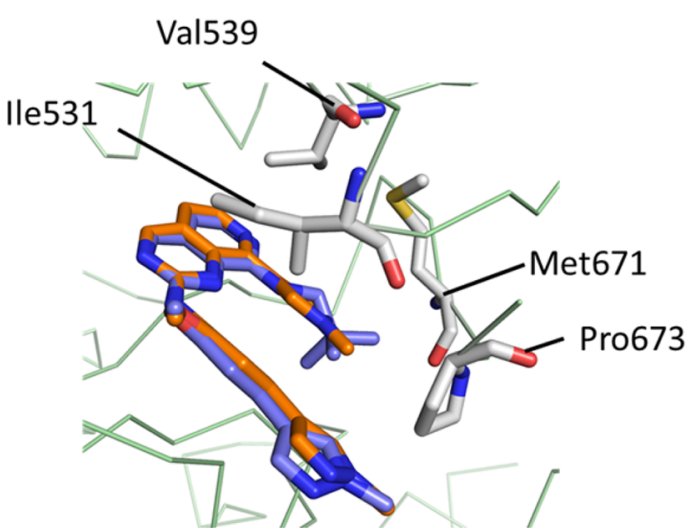

Figure 6. Superimposed crystal structure of MPS1 (pale green) bound to $24 \mathrm{c}$ (carbon atoms colored orange), extracted from PDB code 5EI8, onto the structure of MPS1 (not shown) bound to 34e (carbon atoms colored blue), PDB code 5EH0, showing the hydrophobic pocket formed by Ile531, Val539, Met671, and Pro673. The bulkier neopentyl substituent of $34 \mathrm{e}$ addresses the pocket to a greater extent than the pyrazole substituent of $\mathbf{2 4 c}$.

\section{CONCLUSIONS}

By merging two distinct chemical series, namely $1 \mathrm{H}$-pyrrolo[3,2c]pyridines and $1 \mathrm{H}$-pyrazolo[4,3-c]pyridines, we successfully fulfilled our aim to discover a new class of MPS1 inhibitors that did not require an acid labile Boc group for potent inhibition. The pyrido $[3,4-d]$ pyrimidine core was unprecedented for kinases, ${ }^{16}$ and our structure guided optimization resulted in potent MPS1 inhibitors of substantially reduced size and lipophilicity compared with the parent $1 H$-pyrrolo[3,2-c]-
Table 6. GI $_{50}$ Values for $34 \mathrm{~h}$ in 3 Day MTT Assay Carried out on Panel of Cell Lines ${ }^{a}$

\begin{tabular}{lll}
\multicolumn{1}{c}{ origin } & cell line & $\mathrm{GI}_{50}(\mu \mathrm{M})$ \\
colon & SW620 & 0.065 \\
head and neck & CAL27 & 0.23 \\
breast & CAL51 & 0.068 \\
pancreatic & Miapaca-2 & 0.25 \\
ovarian & RMG1 & 0.110 \\
prostate & PNT2 & 3.95
\end{tabular}

a" $\mathrm{GI}_{50}$ " indicates a cell proliferation assay carried out by colorimetric 3-(4,5-dimethylthiazol-2-yl)-2,5-diphenyltetrazolium bromide (MTT) assay in a panel of cell lines.

pyridines. Moreover, our optimized compound 34h was devoid of CYP inhibition and proved to be extremely potent in the MPS1 biochemical assay with the ability to target this kinase in cells and to induce significant growth inhibition at nanomolar concentrations. A screen against a large sample of the human kinome revealed a high level of selectivity, especially with regard to mitotic kinases. Most importantly, pyrido[3,4- $d]$ pyrimidine 34h showed a satisfactory pharmacokinetic profile in rodents and effectively inhibited MPS1 activity in vivo.

Optimization of the remaining issues associated with $34 \mathrm{~h}$, in particular HLM instability and plasma protein binding, as well as the investigation of advanced compounds in combination efficacy models, is ongoing and the results will be reported in due course.

Table 5. Biochemical, Cellular, And Mouse Microsomal Turnover Data for Enantiomers 34g and $34 \mathrm{~h}^{a}$

\begin{tabular}{|c|c|c|c|c|c|c|c|c|c|c|}
\hline \multirow{3}{*}{ Compd } & \multirow{3}{*}{$\mathbf{R}$} & \multicolumn{5}{|c|}{ Biochemical activity $(\mu \mathrm{M})$} & \multicolumn{2}{|c|}{$\begin{array}{c}\text { Cellular activity } \\
(\mu \mathrm{M})\end{array}$} & \multirow{3}{*}{$\begin{array}{c}\text { MLM } \\
\% \\
\mathbf{( 3 0} \\
\text { min) }\end{array}$} & \multirow{3}{*}{$\begin{array}{l}\text { AlogP/ } \\
\text { L.E. }\end{array}$} \\
\hline & & \multirow{2}{*}{ MPS1 } & \multicolumn{2}{|c|}{$\begin{array}{c}\text { MPS1 } \\
\text { (1 mM ATP) }\end{array}$} & \multicolumn{2}{|c|}{ CDK2 } & \multirow{2}{*}{$\begin{array}{c}\text { P- } \\
\text { MPS1 } \\
\text { IC }_{50}\end{array}$} & \multirow{2}{*}{$\begin{array}{c}\text { HCT } \\
116 \\
\text { GI }_{50}\end{array}$} & & \\
\hline & & & $\mathrm{IC}_{50}$ & $\mathbf{K}_{\mathbf{i}}$ & $\mathrm{IC}_{50}$ & $\mathbf{K}_{\mathbf{i}}$ & & & & \\
\hline $34 \mathrm{e}$ & & $\begin{array}{c}0.018 \\
\pm \\
0.017^{b}\end{array}$ & $\begin{array}{c}0.045 \\
\pm \\
0.023\end{array}$ & 0.0005 & $\begin{array}{c}0.45 \\
\pm \\
0.21\end{array}$ & 0.23 & $\begin{array}{c}0.14 \\
(0.15 \\
0.14)\end{array}$ & $\begin{array}{c}0.34 \\
(0.24 \\
0.43)\end{array}$ & 31 & $\begin{array}{l}4.27 / \\
0.35\end{array}$ \\
\hline $34 \mathrm{~g}$ & & $\begin{array}{c}0.022 \\
\pm \\
0.014^{\mathrm{b}}\end{array}$ & $\begin{array}{c}0.42 \\
\pm \\
0.23\end{array}$ & 0.0042 & $\begin{array}{c}0.47 \\
\pm \\
0.25\end{array}$ & 0.24 & $\begin{array}{c}0.19 \\
\pm \\
0.08\end{array}$ & 0.22 & 25 & $\begin{array}{l}4.65 / \\
0.33\end{array}$ \\
\hline $34 h$ & & $\begin{array}{c}0.011 \\
\pm \\
0.005^{\mathrm{b}}\end{array}$ & $\begin{array}{c}0.020 \\
\pm \\
0.013\end{array}$ & 0.0002 & $\begin{array}{c}0.56 \\
(0.71 \\
0.41)\end{array}$ & 0.28 & $\begin{array}{c}0.059 \\
\pm \\
0.022\end{array}$ & $\begin{array}{r}0.16 \\
(0.15 \\
0.16)\end{array}$ & 27 & $\begin{array}{l}4.65 / \\
0.35\end{array}$ \\
\hline
\end{tabular}

${ }^{a}$ Results are mean $( \pm \mathrm{SD})$ for $n \geq 3$, or mean values of two independent determinations with individual determinations in parentheses or samples run $n=1$. "P-MPS1" indicates an electrochemiluminescence MSD-based cellular assay that measured autophosphorylation of ectopically expressed MPS1 in HCT116 cells. "HCT116 GI " indicates a cell proliferation assay carried out by colorimetric 3-(4,5-dimethylthiazol-2-yl)-2,5diphenyltetrazolium bromide (MTT) assay in HCT116 cells. ${ }^{b}$ Potency at the lower limit of the dynamic range of the Caliper assay run at $10 \mu \mathrm{M}$ ATP concentration. $\mathrm{IC}_{50}$ value is likely to be lower than that quoted. 
Table 7. Mouse and Rat Blood Pharmacokinetics of $34 \mathrm{~h}$ at $5 \mathrm{mg} / \mathrm{kg}$ iv and po

\begin{tabular}{|c|c|c|c|c|c|c|c|}
\hline species & $t_{1 / 2}(\mathrm{~h})$ & $\mathrm{Cl}(\mathrm{mL} / \mathrm{min} / \mathrm{kg})$ & $\mathrm{Cmax}_{\mathrm{po}}(\mathrm{nmol} / \mathrm{L})$ & $\mathrm{AUC}_{\mathrm{po}}(\mathrm{nmol} \cdot \mathrm{h} / \mathrm{L})$ & PPB (\%) & $V_{\mathrm{ss}}(\mathrm{L} / \mathrm{kg})$ & $F(\%)$ \\
\hline mouse & 8.2 & 28 & 770 & 4800 & 99.98 & 14.7 & 68 \\
\hline rat & $2.5^{a}$ & 24 & 560 & 9300 & 99.97 & 4.64 & 100 \\
\hline
\end{tabular}
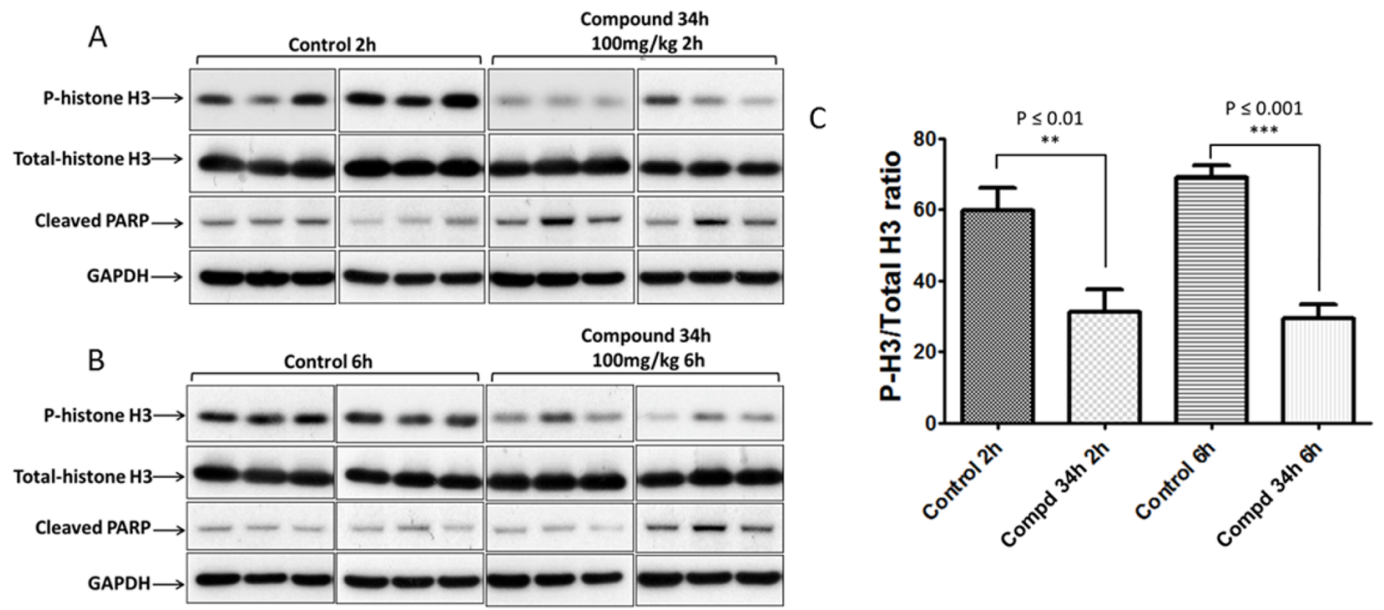

Figure 7. (A,B) Representative immunoblots of phospho-histone H3 showing dose-dependent PD modulation in HCT116 human tumor xenografts, following $100 \mathrm{mg} / \mathrm{kg}$ b.i.d. dosing of $\mathbf{3 4 h}$ for 3 consecutive days. Total histone H3, cleaved poly ADP ribose polymerase (PARP, a measure of apoptosis) and glyceraldehyde 3-phosphate dehydrogenase (GADPH, for protein loading) are also shown. (C) Phospho-histone H3 versus total histone H3 ratio for control and treated samples at 2 and $6 \mathrm{~h}$ after last dose. Asterisks show statistically significant differences from control groups as determined by oneway ANOVA.

\section{EXPERIMENTAL SECTION}

General Chemistry Information. Starting materials, reagents, and solvents for reactions were reagent grade and used as purchased. Chromatography solvents were HPLC grade and were used without further purification. Thin-layer chromatography analysis was performed using silica gel 60 F-254 thin-layer plates. Flash column chromatography was carried out using columns prepacked with $40-63 \mu \mathrm{m}$ silica. Microwave-assisted reactions were carried out using a Biotage Initiator microwave system. LCMS and HRMS analyses were performed on a HPLC system with diode array detector operating at $254 \mathrm{~nm}$, fitted with a reverse-phase $50 \times 4.6 \mathrm{~mm}$ column at a temperature of $22{ }^{\circ} \mathrm{C}$, connected to a time of flight mass spectrometer (ESI). The following solvent system, at a flow rate of $2 \mathrm{~mL} / \mathrm{min}$, was used: Solvent A: methanol; solvent B: $0.1 \%$ formic acid in water. Gradient elution was as follows: 1:9 (A:B) to 9:1 (A:B) over $2.5 \mathrm{~min}, 9: 1$ (A:B) for $1 \mathrm{~min}$ then reversion back to $1: 9(\mathrm{~A}: \mathrm{B})$ over $0.3 \mathrm{~min}, 1: 9(\mathrm{~A}: \mathrm{B})$ for $0.2 \mathrm{~min} .{ }^{1} \mathrm{H}$ NMR spectra were recorded on a Bruker Avance $500 \mathrm{MHz}$ spectrometer using an internal deuterium lock. NMR data is given as follows: chemical shift $(\delta)$ in ppm, multiplicity, coupling constants $(J)$ given in $\mathrm{Hz}$ and integration. The purity of final compounds was determined by HPLC as described above and is $\geq 95 \%$ unless specified otherwise.

Compounds 2-methoxy-4-(1-methyl- $1 H$-pyrazol-4-yl)aniline (23), ${ }^{17}$ 8-chloro-2-(methylsulfonyl)pyrido[3,4-d]pyrimidine (25), ${ }^{16} \mathrm{~N}$-(2-methoxy-4-(1-methyl-1H-pyrazol-4-yl)phenyl)formamide (26a), ${ }^{16} 8$ chloro- $\mathrm{N}$-(2-methoxy-4-(1-methyl-1H-pyrazol-4-yl)phenyl)pyrido[3,4d]pyrimidin-2-amine (27a), ${ }^{16}$ and 2 -(methylthio)pyrido $[3,4-d]$ pyrimidin- $8(7 \mathrm{H})$-one $(35)^{16}$ were synthesized using previously published procedures.

3-Chloro-5-(furan-2-yl)isoquinoline 10. A suspension of 5-bromo3-chloroisoquinoline 9 ( $58 \mathrm{mg}, 0.24 \mathrm{mmol}$ ), furan-2-ylboronic acid (32 $\mathrm{mg}, 0.29 \mathrm{mmol})$, and $\mathrm{Pd}(\mathrm{dppf}) \mathrm{Cl}_{2} \cdot \mathrm{CH}_{2} \mathrm{Cl}_{2}(20 \mathrm{mg}, 0.024 \mathrm{mmol})$ in DME $(0.5 \mathrm{~mL})$ and sodium carbonate $(2 \mathrm{M}, 0.24 \mathrm{~mL})$ was heated to 105 ${ }^{\circ} \mathrm{C}$ under microwave irradiation for $1 \mathrm{~h}$. The mixture was concentrated onto silica gel and purified by flash column chromatography $(0-50 \%$ EtOAc in cyclohexane) to give the title compound (41 $\mathrm{mg}, 75 \%$ ). HRMS (ESI) $\mathrm{m} / z$ calcd for $\mathrm{C}_{13} \mathrm{H}_{9} \mathrm{ClNO}(\mathrm{M}+\mathrm{H}) 230.0367$, found 230.0343. ${ }^{1} \mathrm{H}$ NMR $\left(500 \mathrm{MHz}, \mathrm{CDCl}_{3}\right) \delta 9.09(\mathrm{~s}, 1 \mathrm{H}), 8.33(\mathrm{~s}, 1 \mathrm{H})$, $7.99-7.90(\mathrm{~m}, 2 \mathrm{H}), 7.71-7.55(\mathrm{~m}, 2 \mathrm{H}), 6.79(\mathrm{dd}, J=3.4,0.6 \mathrm{~Hz}, 1 \mathrm{H})$, $6.62(\mathrm{dd}, J=3.4,1.8 \mathrm{~Hz}, 1 \mathrm{H})$.

3-Chloro-5-(1-methyl-1H-pyrazol-4-yl)isoquinoline 11. A suspension of 5-bromo-3-chloroisoquinoline 9 (300 mg, $1.24 \mathrm{mmol})$, 1methyl-4-(4,4,5,5-tetramethyl-1,3,2-dioxaborolan-2-yl)- $1 H$-pyrazole (309 mg, $1.49 \mathrm{mmol}$ ), and $\mathrm{Pd}(\mathrm{dppf}) \mathrm{Cl}_{2} \cdot \mathrm{CH}_{2} \mathrm{Cl}_{2}(105 \mathrm{mg}, 0.124 \mathrm{mmol})$ in DME $(2.5 \mathrm{~mL})$ and sodium carbonate $(2 \mathrm{M}, 1.24 \mathrm{~mL})$ was heated to $105{ }^{\circ} \mathrm{C}$ under microwave irradiation for $1.5 \mathrm{~h}$. The mixture was concentrated onto silica gel and purified by flash column chromatography (0-100\% EtOAc in cyclohexane) to give the title compound (324 $\mathrm{mg}$, quant.). HRMS (ESI) $\mathrm{m} / z$ calcd for $\mathrm{C}_{13} \mathrm{H}_{11} \mathrm{ClN}_{3}(\mathrm{M}+\mathrm{H})$ 244.0636, found 244.0639. ${ }^{1} \mathrm{H} \mathrm{NMR}\left(500 \mathrm{MHz}, \mathrm{CDCl}_{3}\right) \delta 9.08(\mathrm{~s}, 1 \mathrm{H})$, $7.96(\mathrm{~s}, 1 \mathrm{H}), 7.90(\mathrm{~d}, J=8.1 \mathrm{~Hz}, 1 \mathrm{H}), 7.73(\mathrm{~s}, 1 \mathrm{H}), 7.67-7.55(\mathrm{~m}, 3 \mathrm{H})$, $4.05(\mathrm{~s}, 3 \mathrm{H})$.

5-(Furan-2-yl)-N-(4-methoxyphenyl)isoquinolin-3-amine 14. A suspension of 3-chloro-5-(furan-2-yl)isoquinoline $10(41 \mathrm{mg}, 0.18$ mmol), 4-methoxyaniline $12(29 \mathrm{mg}, 0.23 \mathrm{mmol})$, cesium carbonate (204 mg, $0.626 \mathrm{mmol}),{ }^{t} \mathrm{BuXPhos}(30 \mathrm{mg}, 0.071 \mathrm{mmol}), \mathrm{Pd}_{2}(\mathrm{dba})_{3}(16$ $\mathrm{mg}, 0.018 \mathrm{mmol})$, and ${ }^{\mathrm{t}} \mathrm{BuOH}\left(3 \% \mathrm{H}_{2} \mathrm{O}\right)(1 \mathrm{~mL})$ was heated to $80{ }^{\circ} \mathrm{C}$ under microwave irradiation for $3 \mathrm{~h}$. The mixture was concentrated onto silica gel and purified by flash column chromatography $(0-100 \%$ EtOAc in cyclohexane) to give the title compound (10 mg, 18\%). HRMS (ESI) $m / z$ calcd for $\mathrm{C}_{20} \mathrm{H}_{17} \mathrm{~N}_{2} \mathrm{O}_{2}(\mathrm{M}+\mathrm{H}) 317.1285$, found $317.1282 .{ }^{1} \mathrm{H}$ NMR $\left(500 \mathrm{MHz}, \mathrm{CDCl}_{3}\right) \delta 8.95(\mathrm{~s}, 1 \mathrm{H}), 7.84-7.75(\mathrm{~m}, 2 \mathrm{H}), 7.61(\mathrm{~s}$, $1 \mathrm{H}), 7.57(\mathrm{~s}, 1 \mathrm{H}), 7.58-7.25(\mathrm{~m}, 3 \mathrm{H}), 7.17-6.90(\mathrm{~m}, 2 \mathrm{H}), 6.77-6.60$ $(\mathrm{m}, 2 \mathrm{H}), 6.54(\mathrm{dd}, J=3.3,1.8 \mathrm{~Hz}, 1 \mathrm{H}), 3.85(\mathrm{~s}, 3 \mathrm{H})$.

$\mathrm{N}$-(4-Methoxyphenyl)-5-(1-methyl-1H-pyrazol-4-yl)isoquinolin-3amine 15a. A suspension of 3-chloro-5-(1-methyl-1H-pyrazol-4yl)isoquinoline 11 (55 mg, $0.23 \mathrm{mmol}$ ), 4-methoxyaniline 12 (36 mg, $0.29 \mathrm{mmol})$, cesium carbonate $(257 \mathrm{mg}, 0.789 \mathrm{mmol}),{ }^{t}$ BuXPhos $(38$ $\mathrm{mg}, 0.090 \mathrm{mmol}), \mathrm{Pd}_{2}(\mathrm{dba})_{3}(21 \mathrm{mg}, 0.023 \mathrm{mmol})$, and ${ }^{t} \mathrm{BuOH}(3 \%$ $\left.\mathrm{H}_{2} \mathrm{O}\right)(1 \mathrm{~mL})$ was heated to $80^{\circ} \mathrm{C}$ under microwave irradiation for $1.5 \mathrm{~h}$ The mixture was concentrated onto silica gel and purified by flash column chromatography $(0-100 \%$ EtOAc in cyclohexane) to give the title compound ( $6 \mathrm{mg}, 8 \%$ ). HRMS (ESI) $\mathrm{m} / z$ calcd for $\mathrm{C}_{20} \mathrm{H}_{19} \mathrm{~N}_{4} \mathrm{O}$ (M $+\mathrm{H}) 331.1553$, found 331.1546. ${ }^{1} \mathrm{H}$ NMR $\left(500 \mathrm{MHz}, \mathrm{CDCl}_{3}\right) \delta 8.95(\mathrm{~s}$, $1 \mathrm{H}), 7.75(\mathrm{~d}, J=8.2 \mathrm{~Hz}, 1 \mathrm{H}), 7.68(\mathrm{~s}, 1 \mathrm{H}), 7.52(\mathrm{~s}, 1 \mathrm{H}), 7.50-7.46(\mathrm{~m}$, 
$2 \mathrm{H}), 7.31-7.21(\mathrm{~m}, 3 \mathrm{H}), 7.03-6.89(\mathrm{~m}, 2 \mathrm{H}), 6.48(\mathrm{~s}, 1 \mathrm{H}), 3.98(\mathrm{~s}, 3 \mathrm{H})$, $3.83(\mathrm{~s}, 3 \mathrm{H})$

N-(2,4-Dimethoxyphenyl)-5-(1-methyl-1H-pyrazol-4-yl)isoquinolin-3-amine 15b. A suspension of 3-chloro-5-(1-methyl-1Hpyrazol-4-yl)isoquinoline 11 ( $55 \mathrm{mg}, 0.23 \mathrm{mmol}$ ), 2,4-dimethoxyaniline $13(45 \mathrm{mg}, 0.29 \mathrm{mmol})$, cesium carbonate $(257 \mathrm{mg}, 0.789 \mathrm{mmol})$, ${ }^{t}$ BuXPhos (38 mg, $\left.0.090 \mathrm{mmol}\right), \mathrm{Pd}_{2}(\mathrm{dba})_{3}(21 \mathrm{mg}, 0.023 \mathrm{mmol})$, and ${ }^{t} \mathrm{BuOH}\left(3 \% \mathrm{H}_{2} \mathrm{O}\right)(1 \mathrm{~mL})$ was heated to $80{ }^{\circ} \mathrm{C}$ under microwave irradiation for $1.5 \mathrm{~h}$ and then to $100{ }^{\circ} \mathrm{C}$ for $1.5 \mathrm{~h}$. The mixture was concentrated onto silica gel and purified by flash column chromatography $(0-100 \%$ EtOAc in cyclohexane) to give the title compound (22 $\mathrm{mg}, 27 \%$ ). HRMS (ESI) $\mathrm{m} / z$ calcd for $\mathrm{C}_{21} \mathrm{H}_{21} \mathrm{~N}_{4} \mathrm{O}_{2}(\mathrm{M}+\mathrm{H}) 361.1659$, found 361.1661. ${ }^{1} \mathrm{H} \mathrm{NMR}\left(500 \mathrm{MHz}, \mathrm{CDCl}_{3}\right) \delta 8.96(\mathrm{~s}, 1 \mathrm{H}), 7.78-7.69$ $(\mathrm{m}, 2 \mathrm{H}), 7.61(\mathrm{~d}, J=8.6 \mathrm{~Hz}, 1 \mathrm{H}), 7.54(\mathrm{~s}, 1 \mathrm{H}), 7.47(\mathrm{dd}, J=7.0,1.0 \mathrm{~Hz}$, $1 \mathrm{H}), 7.33-7.23(\mathrm{~m}, 2 \mathrm{H}), 6.73(\mathrm{~s}, 1 \mathrm{H}), 6.58-6.49(\mathrm{~m}, 2 \mathrm{H}), 3.99(\mathrm{~s}, 3 \mathrm{H})$, $3.85(\mathrm{~s}, 3 \mathrm{H}), 3.83(\mathrm{~s}, 3 \mathrm{H})$.

Preparation of Compounds in Scheme 2 (Exemplified by the Preparation of Compounds 24a, 24d, 28a, and 28b). 8-(1-Methyl1 -pyrazol-4-yl)-2-(methylthio)pyrido[3,4-d]pyrimidine 17. A solution of 8-chloro-2-(methylthio)pyrido[3,4-d]pyrimidine 16 (480 mg, $2.27 \mathrm{mmol}),(1-\mathrm{methyl}-1 \mathrm{H}$-pyrazol-4-yl)boronic acid pinacol ester (940 $\mathrm{mg}, 4.52 \mathrm{mmol})$, and $\mathrm{Pd}(\mathrm{dppf}) \mathrm{Cl}_{2} \cdot \mathrm{CH}_{2} \mathrm{Cl}_{2}(100 \mathrm{mg}, 0.122 \mathrm{mmol})$ in THF $(15 \mathrm{~mL})$ and sodium carbonate $(2 \mathrm{M}, 5 \mathrm{~mL})$ was heated to $65^{\circ} \mathrm{C}$ for $18 \mathrm{~h}$. The mixture was diluted with EtOAc and quenched with brine. The aqueous layer was extracted with EtOAc three times. The combined organics were washed with water and brine, dried, and concentrated in vacuo. The residue was purified by flash column chromatography (0$4 \% \mathrm{MeOH}$ in $\mathrm{CH}_{2} \mathrm{Cl}_{2}$ ) to give the title compound (658 $\mathrm{mg}$, quant). HRMS (ESI) $m / z$ calcd for $\mathrm{C}_{12} \mathrm{H}_{12} \mathrm{~N}_{5} \mathrm{~S}(\mathrm{M}+\mathrm{H})$ 258.0813, found 258.0817. ${ }^{1} \mathrm{H}$ NMR $\left(500 \mathrm{MHz}, \mathrm{CDCl}_{3}\right) \delta 9.22(\mathrm{~s}, 1 \mathrm{H}), 8.67(\mathrm{~s}, 1 \mathrm{H})$, $8.63-8.56(\mathrm{~m}, 2 \mathrm{H}), 7.47(\mathrm{~d}, J=5.3 \mathrm{~Hz}, 1 \mathrm{H}), 4.05(\mathrm{~s}, 3 \mathrm{H}), 2.78(\mathrm{~s}, 3 \mathrm{H})$.

8-Cyclopropyl-2-(methylthio)pyrido[3,4-d]pyrimidine 18. A solution of 8-chloro-2-(methylthio)pyrido[3,4-d]pyrimidine $16(20 \mathrm{mg}$, $0.094 \mathrm{mmol}$ ), cyclopropyl boronic acid (11 mg, $0.13 \mathrm{mmol}), \mathrm{PCy}_{3}(3$ $\mathrm{mg}, 11 \mu \mathrm{mol}), \mathrm{K}_{3} \mathrm{PO}_{4}(70 \mathrm{mg}, 0.32 \mathrm{mmol})$, and $\mathrm{Pd}(\mathrm{OAc})_{2}(1.0 \mathrm{mg}, 4.5$ $\mu \mathrm{mol})$ was dissolved in toluene/water $(6: 1,1 \mathrm{~mL})$ and heated to $95^{\circ} \mathrm{C}$ for $18 \mathrm{~h}$. The mixture was diluted with EtOAc and quenched with brine. The aqueous layer was extracted with EtOAc three times. The combined organics were washed with water and brine, dried, and concentrated in vacuo. The residue was purified by flash column chromatography (0$20 \%$ EtOAc in cyclohexane) to give the title compound (13 mg, 62\%). HRMS (ESI) $m / z$ calcd $\mathrm{C}_{11} \mathrm{H}_{12} \mathrm{~N}_{3} \mathrm{~S}(\mathrm{M}+\mathrm{H}) 218.0746$, found 218.0751 . ${ }^{1} \mathrm{H} \mathrm{NMR}\left(500 \mathrm{MHz}, \mathrm{CDCl}_{3}\right) \delta 9.18(\mathrm{~s}, 1 \mathrm{H}), 8.46(\mathrm{~d}, J=5.4 \mathrm{~Hz}, 1 \mathrm{H})$, $7.37(\mathrm{~d}, J=5.5 \mathrm{~Hz}, 1 \mathrm{H}), 3.46(\mathrm{tt}, J=8.2,4.8 \mathrm{~Hz}, 1 \mathrm{H}), 2.74(\mathrm{~s}, 3 \mathrm{H}), 1.34-$ $1.27(\mathrm{~m}, 2 \mathrm{H}), 1.25-1.17(\mathrm{~m}, 2 \mathrm{H})$.

8-(1-Methyl-1H-pyrazol-4-yl)-2-(methylsulfonyl)pyrido[3,4-d]pyrimidine 19. A suspension of 8-(1-methyl-1H-pyrazol-4-yl)-2(methylthio)pyrido[3,4-d]pyrimidine $17(584 \mathrm{mg}, 2.27 \mathrm{mmol})$ in $\mathrm{CH}_{2} \mathrm{Cl}_{2}(22 \mathrm{~mL})$ was treated with $m$-CPBA $(77 \% \mathrm{w} / \mathrm{w}, 1.12 \mathrm{~g}, 4.98$ $\mathrm{mmol}$ ) at $0{ }^{\circ} \mathrm{C}$ and then allowed to reach rt over $18 \mathrm{~h}$. The mixture was quenched with water and extracted with $\mathrm{CH}_{2} \mathrm{Cl}_{2}$. The combined organics were washed with water, dried, and concentrated in vacuo. The residue was purified by flash column chromatography (0-100\% EtOAc in cyclohexane) to give the title compound (408 mg, 62\%). HRMS (ESI) $m / z$ calcd for $\mathrm{C}_{12} \mathrm{H}_{12} \mathrm{~N}_{5} \mathrm{O}_{2} \mathrm{~S}(\mathrm{M}+\mathrm{H}) 290.0706$, found 290.0722 . ${ }^{1} \mathrm{H}$ NMR $\left(500 \mathrm{MHz},\left(\mathrm{CD}_{3}\right)_{2} \mathrm{SO}\right) \delta 10.00(\mathrm{~s}, 1 \mathrm{H}), 8.91(\mathrm{~d}, J=5.4 \mathrm{~Hz}$, $1 \mathrm{H}), 8.81(\mathrm{~s}, 1 \mathrm{H}), 8.53(\mathrm{~s}, 1 \mathrm{H}), 7.99(\mathrm{~d}, J=5.4 \mathrm{~Hz}, 1 \mathrm{H}), 3.99(\mathrm{~s}, 3 \mathrm{H})$, $3.59(\mathrm{~s}, 3 \mathrm{H})$.

8-Cyclopropyl-2-(methylsulfonyl)pyrido[3,4-d]pyrimidine 20. A suspension of 8-cyclopropyl-2-(methylthio)pyrido[3,4-d]pyrimidine $18(127 \mathrm{mg}, 0.584 \mathrm{mmol})$ in $\mathrm{CH}_{2} \mathrm{Cl}_{2}(5 \mathrm{~mL})$ was treated with $\mathrm{m}$ CPBA $(77 \% \mathrm{w} / \mathrm{w}, 290 \mathrm{mg}, 1.29 \mathrm{mmol})$ at $0{ }^{\circ} \mathrm{C}$ and then allowed to reach rt over $18 \mathrm{~h}$. The mixture was quenched with water and extracted with $\mathrm{CH}_{2} \mathrm{Cl}_{2}$. The combined organics were washed with water, dried, and concentrated onto silica. The residue was purified by flash column chromatography $(0-70 \%$ EtOAc in cyclohexane) to give the title compound (128 mg, 88\%). HRMS (ESI) $m / z$ calcd $\mathrm{C}_{11} \mathrm{H}_{12} \mathrm{~N}_{3} \mathrm{O}_{2} \mathrm{~S}(\mathrm{M}+$ H) 250.0645 , found $250.0648 .{ }^{1} \mathrm{H}$ NMR $\left(500 \mathrm{MHz},\left(\mathrm{CD}_{3}\right)_{2} \mathrm{SO}\right) \delta 9.99$ $(\mathrm{s}, 1 \mathrm{H}), 8.79(\mathrm{~d}, J=5.5 \mathrm{~Hz}, 1 \mathrm{H}), 7.94(\mathrm{~d}, J=5.5 \mathrm{~Hz}, 1 \mathrm{H}), 3.56(\mathrm{~s}, 3 \mathrm{H})$, $3.44(\mathrm{~m}, 1 \mathrm{H}), 1.30-1.25(\mathrm{~m}, 2 \mathrm{H}), 1.24-1.20(\mathrm{~m}, 2 \mathrm{H})$.
$\mathrm{N}$-(4-Methoxyphenyl)-8-(1-methyl-1H-pyrazol-4-yl)pyrido[3,4-d]pyrimidin-2-amine 24a. To a solution of 8-(1-methyl-1H-pyrazol-4yl)-2-(methylsulfonyl)pyrido[3,4- $d]$ pyrimidine $19(29 \mathrm{mg}, 0.10 \mathrm{mmol})$ in DMSO $(4 \mathrm{~mL})$ was added cesium carbonate $(59 \mathrm{mg}, 0.18 \mathrm{mmol})$ and $\mathrm{N}$-(4-methoxyphenyl)formamide ( $15 \mathrm{mg}, 0.10 \mathrm{mmol})$. The mixture was heated to $100{ }^{\circ} \mathrm{C}$ for $18 \mathrm{~h}$. The mixture was diluted with EtOAc and water. The aqueous layer was re-extracted with EtOAc. The combined organics were washed with brine, dried, and concentrated in vacuo. The residue was purified by flash column chromatography $(0-10 \% \mathrm{MeOH}$ in $\mathrm{CH}_{2} \mathrm{Cl}_{2}$ ), followed by SCX-2 cartridge $\left(\mathrm{MeOH}-1 \mathrm{M} \mathrm{NH}_{3}\right.$ in $\left.\mathrm{MeOH}\right)$ to give the title compound ( $8 \mathrm{mg}, 24 \%$ ). HRMS (ESI) $\mathrm{m} / z$ calcd $\mathrm{C}_{18} \mathrm{H}_{16} \mathrm{~N}_{6} \mathrm{O}(\mathrm{M}+\mathrm{H}) 333.1464$, found 333.1450. ${ }^{1} \mathrm{H}$ NMR $(500 \mathrm{MHz}$, $\left.\mathrm{CD}_{3} \mathrm{OD}\right) \delta 9.24(\mathrm{~s}, 1 \mathrm{H}), 8.38(\mathrm{~s}, 1 \mathrm{H}), 8.29(\mathrm{~d}, J=5.4 \mathrm{~Hz}, 1 \mathrm{H}), 7.63-$ $7.59(\mathrm{~m}, 3 \mathrm{H}), 7.54(\mathrm{~d}, J=5.4 \mathrm{~Hz}, 1 \mathrm{H}), 7.05(\mathrm{~d}, J=8.9 \mathrm{~Hz}, 2 \mathrm{H}), 3.91(\mathrm{~s}$, $3 \mathrm{H}), 3.87(\mathrm{~s}, 3 \mathrm{H})$.

8-Cyclopropyl-N-(2-methoxy-4-(1-methyl-1H-pyrazol-4-yl)phenyl)pyrido[3,4-d]pyrimidin-2-amine $24 d$. A solution of 2 methoxy-4-(1-methyl-1H-pyrazol-4-yl)aniline $23(50 \mathrm{mg}, 0.25 \mathrm{mmol})$, TFA ( $45 \mu \mathrm{L}, 0.60 \mathrm{mmol}$ ), and 8-cyclopropyl-2-(methylsulfonyl)pyrido$[3,4-d]$ pyrimidine $20(31 \mathrm{mg}, 0.12 \mathrm{mmol})$ in 2,2,2-trifluoroethanol (0.7 $\mathrm{mL}$ ) was heated to $130{ }^{\circ} \mathrm{C}$ under microwave irradiation for $1.5 \mathrm{~h}$. The reaction was diluted with EtOAc and quenched with aqueous sat. sodium bicarbonate. The aqueous layer was extracted with EtOAc, and the combined organics were washed with water and brine, dried, and concentrated in vacuo. The residue was purified by flash column chromatography $(0-60 \%$ EtOAc in cyclohexane) to give the title compound $\left(20 \mathrm{mg}\right.$, 43\%). HRMS (ESI) $\mathrm{m} / z$ calcd for $\mathrm{C}_{21} \mathrm{H}_{21} \mathrm{~N}_{6} \mathrm{O}(\mathrm{M}+$ H) 373.1771, found 373.1773. ${ }^{1} \mathrm{H}$ NMR $\left(500 \mathrm{MHz},\left(\mathrm{CD}_{3}\right)_{2} \mathrm{SO}\right) \delta 9.40$ $(\mathrm{s}, 1 \mathrm{H}), 8.54(\mathrm{~s}, 1 \mathrm{H}), 8.41(\mathrm{~d}, J=8.3 \mathrm{~Hz}, 1 \mathrm{H}), 8.28(\mathrm{~d}, J=5.3 \mathrm{~Hz}, 1 \mathrm{H})$, $8.17(\mathrm{~d}, J=0.9 \mathrm{~Hz}, 1 \mathrm{H}), 7.90(\mathrm{~d}, J=0.8 \mathrm{~Hz}, 1 \mathrm{H}), 7.56(\mathrm{~d}, J=5.3 \mathrm{~Hz}$, $1 \mathrm{H}), 7.30(\mathrm{~d}, J=1.8 \mathrm{~Hz}, 1 \mathrm{H}), 7.25(\mathrm{dd}, J=8.2,1.8 \mathrm{~Hz}, 1 \mathrm{H}), 3.96(\mathrm{~s}, 3 \mathrm{H})$, $3.88(\mathrm{~s}, 3 \mathrm{H}), 3.24(\mathrm{~m}, 1 \mathrm{H}), 1.16-1.08(\mathrm{~m}, 4 \mathrm{H})$.

Preparation of Formamides $26 \mathrm{~b}-\mathrm{e}$ (Exemplified by Preparation of Compound 26b). N-(2-Methyl-4-(1-methyl-1H-pyrazol-4yl)phenyl)formamide 26b. A solution of 2-methyl-4-(1-methyl-1Hpyrazol-4-yl)aniline $\mathbf{S 1}(100 \mathrm{mg}, 0.534 \mathrm{mmol})$ in formic acid $(3 \mathrm{~mL})$ was heated to $100{ }^{\circ} \mathrm{C}$ for $3 \mathrm{~h}$. The mixture was concentrated in vacuo. The residue was partitioned between aqueous sat. sodium bicarbonate and EtOAc. The aqueous layer was re-extracted with EtOAc. The combined organics were washed with water and brine, dried, and concentrated in vacuo. The residue was purified by flash column chromatography $(0-$ $10 \% \mathrm{MeOH}$ in EtOAc) to give the title compound $(160 \mathrm{mg}, 34 \%)$. HRMS (ESI) $m / z$ calcd for $\mathrm{C}_{12} \mathrm{H}_{14} \mathrm{~N}_{3} \mathrm{O}(\mathrm{M}+\mathrm{H})$ 216.1131, found 216.1141. ${ }^{1} \mathrm{H}$ NMR $\left(500 \mathrm{MHz}, \mathrm{CD}_{3} \mathrm{OD}\right) \delta 8.31(\mathrm{~s}, 1 \mathrm{H}), 7.93(\mathrm{~s}, 1 \mathrm{H})$, $7.80(\mathrm{~s}, 1 \mathrm{H}), 7.67(\mathrm{~d}, J=8.0 \mathrm{~Hz}, 1 \mathrm{H}), 7.44(\mathrm{~d}, J=2.0 \mathrm{~Hz}, 1 \mathrm{H}), 7.38(\mathrm{dd}, J$ $=8.0,2.0, \mathrm{~Hz}, 1 \mathrm{H}), 3.92(\mathrm{~s}, 3 \mathrm{H}), 2.31(\mathrm{~s}, 3 \mathrm{H})$.

8-Chloro-N-(2-methyl-4-(1-methyl-1H-pyrazol-4-yl)phenyl)pyrido[3,4-d]pyrimidin-2-amine $27 \mathrm{~b}$. To a cooled $\left(0{ }^{\circ} \mathrm{C}\right)$ suspension of $\mathrm{N}$-(2-methyl-4-(1-methyl-1H-pyrazol-4-yl)phenyl)formamide $\mathbf{2 6 \mathbf { b }}$ $(40 \mathrm{mg}, 0.19 \mathrm{mmol})$ in THF $(4 \mathrm{~mL})$ was added sodium hydride $(60 \%$ $\mathrm{w} / \mathrm{w}$ dispersion in oil, $12 \mathrm{mg}, 0.30 \mathrm{mmol})$. The reaction mixture was stirred at rt for $10 \mathrm{~min}$. The mixture was cooled to $0{ }^{\circ} \mathrm{C}$, and 8-chloro-2(methylthio)pyrido[3,4-d]pyrimidine $\mathbf{2 5}^{16}$ (60 $\mathrm{mg}, 0.24 \mathrm{mmol}$ ) was added. The mixture was stirred for $18 \mathrm{~h}$ while slowly warming to $\mathrm{rt}$ and then concentrated in vacuo, and the residue was partitioned between EtOAc and water. The aqueous layer was extracted with EtOAc and $\mathrm{CH}_{2} \mathrm{Cl}_{2}$. The combined organics were washed with water and brine, dried, and concentrated in vacuo. The residue was purified by flash column chromatography $(0-5 \% \mathrm{MeOH}$ in EtOAc) to give the title compound (79 mg, 97\%). HRMS (ESI) $m / z$ calcd for $\mathrm{C}_{19} \mathrm{H}_{16} \mathrm{ClN}_{6}(\mathrm{M}+$ H) 351.1119 , found 351.1111. ${ }^{1} \mathrm{H} \mathrm{NMR}\left(500 \mathrm{MHz}, \mathrm{CDCl}_{3}\right) \delta 9.17(\mathrm{~s}$, $1 \mathrm{H}), 8.26(\mathrm{~d}, J=5.0 \mathrm{~Hz}, 1 \mathrm{H}), 7.79(\mathrm{~s}, 1 \mathrm{H}), 7.63(\mathrm{~s}, 1 \mathrm{H}), 7.52(\mathrm{~d}, J=5.0$ $\mathrm{Hz}, 1 \mathrm{H}), 7.47$ (dd, $J=8.0,2.0 \mathrm{~Hz}, 1 \mathrm{H}), 7.42(\mathrm{~m}, 1 \mathrm{H}), 7.39(\mathrm{~d}, J=2.0 \mathrm{~Hz}$, $1 \mathrm{H}), 3.98(\mathrm{~s}, 3 \mathrm{H}), 2.44(\mathrm{~s}, 3 \mathrm{H})$.

$\mathrm{N}$-(2-Methoxy-4-(1-methyl-1H-pyrazol-4-yl)phenyl)-8phenylpyrido[3,4-d]pyrimidin-2-amine $28 a$. To a solution of 8chloro- $N$-(2-methoxy-4-(1-methyl-1H-pyrazol-4-yl)phenyl)pyrido[3,4d] pyrimidin-2-amine $27 \mathrm{a}^{16}(25 \mathrm{mg}, 0.068 \mathrm{mmol})$ in 1,4-dioxane/water $(2: 1,3 \mathrm{~mL})$ was added phenyl boronic acid $(17 \mathrm{mg}, 0.14 \mathrm{mmol})$, $\mathrm{Pd}\left(\mathrm{PPh}_{3}\right)_{4}(16 \mathrm{mg}, 0.014 \mathrm{mmol})$, and cesium carbonate $(33 \mathrm{mg}, 0.10$ 
mmol). The reaction was heated to $100^{\circ} \mathrm{C}$ under microwave irradiation for $30 \mathrm{~min}$. The reaction was diluted with EtOAc and water, dried, and concentrated in vacuo. The residue was purified by flash column chromatography (0-100\% EtOAc in cyclohexane) followed by SCX-2 cartridge $\left(\mathrm{MeOH}-1 \mathrm{M} \mathrm{NH}_{3}\right.$ in $\left.\mathrm{MeOH}\right)$ to give the title compound (8 mg, 29\%). HRMS (ESI) $m / z$ calcd for $\mathrm{C}_{24} \mathrm{H}_{21} \mathrm{~N}_{6} \mathrm{O}(\mathrm{M}+\mathrm{H})$ 409.1777, found 409.1771. ${ }^{1} \mathrm{H} \mathrm{NMR}\left(500 \mathrm{MHz}, \mathrm{CD}_{3} \mathrm{OD}\right) \delta 9.37(\mathrm{~s}, 1 \mathrm{H}), 8.56(\mathrm{~d}, J$ $=8.5 \mathrm{~Hz}, 1 \mathrm{H}), 8.50(\mathrm{~d}, J=5.5 \mathrm{~Hz}, 1 \mathrm{H}), 8.11-8.09(\mathrm{~m}, 2 \mathrm{H}), 7.97(\mathrm{~s}, 1 \mathrm{H})$, $7.82(\mathrm{~s}, 1 \mathrm{H}), 7.79(\mathrm{~d}, J=5.5 \mathrm{~Hz}, 1 \mathrm{H}), 7.61-7.59(\mathrm{~m}, 3 \mathrm{H}), 7.19(\mathrm{~d}, J=2.0$ $\mathrm{Hz}, 1 \mathrm{H}), 6.99(\mathrm{dd}, J=8.5,2.0 \mathrm{~Hz}, 1 \mathrm{H}), 4.02(\mathrm{~s}, 3 \mathrm{H}), 3.95(\mathrm{~s}, 3 \mathrm{H})$

8-(1-Methyl-1H-pyrazol-4-yl)-N-(2-methyl-4-(1-methyl-1H-pyrazol-4-yl)phenyl)pyrido[3,4-d]pyrimidin-2-amine $28 b$. To a solution of 8-chloro- $\mathrm{N}$-(2-methyl-4-(1-methyl-1H-pyrazol-4-yl)phenyl)pyrido[3,4-d] pyrimidin-2-amine $27 \mathrm{~b}(12 \mathrm{mg}, 0.034 \mathrm{mmol})$ in 1,4-dioxane/ water $(2: 1,3 \mathrm{~mL})$ were added 1-methyl-4-(4,4,5,5-tetramethyl-1,3,2dioxaborolan-2-yl)-1H-pyrazole (14 mg, $0.068 \mathrm{mmol}$ ), cesium carbonate $(17 \mathrm{mg}, 0.051 \mathrm{mmol})$, and $\mathrm{Pd}\left(\mathrm{PPh}_{3}\right)_{4}(2 \mathrm{mg}, 1.7 \mu \mathrm{mol})$. The reaction mixture was heated to $100{ }^{\circ} \mathrm{C}$ under microwave conditions for $30 \mathrm{~min}$. The reaction mixture was diluted with EtOAc and water. The combined organics were washed with water and brine, dried, and concentrated in vacuo. The residue was purified by flash column chromatography $(0-15 \% \mathrm{MeOH}$ in EtOAc) to give the title compound (7 mg, 52\%). HRMS (ESI) $m / z$ calcd for $\mathrm{C}_{22} \mathrm{H}_{21} \mathrm{~N}_{8}(\mathrm{M}+\mathrm{H})$ 397.1884, found 397.1878. ${ }^{1} \mathrm{H}$ NMR $\left(500 \mathrm{MHz}, \mathrm{CDCl}_{3}\right) \delta 9.16(\mathrm{~s}, 1 \mathrm{H}), 8.43(\mathrm{~d}, J$ $=5.5 \mathrm{~Hz}, 1 \mathrm{H}), 8.40(\mathrm{~d}, J=5.5 \mathrm{~Hz}, 2 \mathrm{H}), 7.86(\mathrm{~d}, J=8.0 \mathrm{~Hz}, 1 \mathrm{H}), 7.82(\mathrm{~s}$, $1 \mathrm{H}), 7.67(\mathrm{~s}, 1 \mathrm{H}), 7.50-7.45(\mathrm{~m}, 2 \mathrm{H}), 7.36(\mathrm{~d}, J=5.5 \mathrm{~Hz}, 1 \mathrm{H}), 7.05(\mathrm{br}$ $\mathrm{s}, 1 \mathrm{H}), 4.00(\mathrm{~s}, 3 \mathrm{H}), 3.77(\mathrm{~s}, 3 \mathrm{H}), 2.39(\mathrm{~s}, 3 \mathrm{H})$.

Preparation of Compounds in Scheme 3 (Exemplified by the Preparation of 33a). 2-(Methylsulfonyl)-8-(pyrrolidin-1-yl)pyrido[3,4-d]pyrimidine 31. A mixture of 8-chloro-2-(methylthio)pyrido[3,4d] pyrimidine 16 (105 mg, $0.496 \mathrm{mmol})$ and pyrrolidine $(425 \mu \mathrm{L}, 5.10$ $\mathrm{mmol})$ in NMP $(2.5 \mathrm{~mL})$ was stirred at $135^{\circ} \mathrm{C}$ for $3 \mathrm{~h}$. The mixture was quenched with aqueous sat. sodium bicarbonate and extracted with EtOAc. The combined organics were washed with water and brine, dried, and concentrated in vacuo to afford the crude sulfide.

A suspension of crude sulfide 29 (ca. $0.496 \mathrm{mmol}$ ) in $\mathrm{CH}_{2} \mathrm{Cl}_{2}(4 \mathrm{~mL})$ was treated with $m$-CPBA $(77 \% \mathrm{w} / \mathrm{w}, 250 \mathrm{mg}, 1.11 \mathrm{mmol})$ at $0{ }^{\circ} \mathrm{C}$ and then allowed to reach $\mathrm{rt}$ for $18 \mathrm{~h}$. An additional portion of $m$-CPBA $(77 \%$ $\mathrm{w} / \mathrm{w}, 60 \mathrm{mg}, 0.27 \mathrm{mmol}$ ) was added at $\mathrm{rt}$, and the mixture stirred for $2 \mathrm{~h}$. The mixture was quenched with water and extracted with $\mathrm{CH}_{2} \mathrm{Cl}_{2}$. The combined organics were washed with aqueous sat. sodium bicarbonate and brine, dried, and concentrated in vacuo. The residue was purified by flash column chromatography (0-70\% EtOAc in cyclohexane) to give the title compound ( $62 \mathrm{mg}, 45 \%$ over two steps). LCMS (ESI) $\mathrm{m} / z 279$ $(\mathrm{M}+\mathrm{H}) .{ }^{1} \mathrm{H}$ NMR $\left(500 \mathrm{MHz},\left(\mathrm{CD}_{3}\right)_{2} \mathrm{SO}\right) \delta 9.62(\mathrm{~s}, 1 \mathrm{H}), 8.30(\mathrm{~d}, J=$ $5.4 \mathrm{~Hz}, 1 \mathrm{H}), 7.11(\mathrm{~d}, J=5.5 \mathrm{~Hz}, 1 \mathrm{H}), 3.97(\mathrm{br} \mathrm{s}, 4 \mathrm{H}), 3.45(\mathrm{~s}, 3 \mathrm{H}), 1.98$ (s, 4H).

$\mathrm{N}$-(2-Methoxy-4-(1-methyl-1H-pyrazol-4-yl)phenyl)-8-(pyrrolidin1-yl)pyrido[3,4-d]pyrimidin-2-amine 33a. A solution of 2-methoxy-4(1-methyl-1H-pyrazol-4-yl)aniline $23(52 \mathrm{mg}, 0.26 \mathrm{mmol})$, TFA ( $50 \mu \mathrm{L}$, $0.65 \mathrm{mmol}$ ) and 2-(methylsulfonyl)-8-(pyrrolidin-1-yl)pyrido[3,4-d]pyrimidine $31(35 \mathrm{mg}, 0.13 \mathrm{mmol})$ in 2,2,2-trifluoroethanol $(0.6 \mathrm{~mL})$ was heated to $130^{\circ} \mathrm{C}$ under microwave irradiation for $2 \mathrm{~h}$. An additional portion of TFA ( $50 \mu \mathrm{L}, 0.65 \mathrm{mmol}$ ) was added, and the mixture was heated to $180{ }^{\circ} \mathrm{C}$ under microwave irradiation for $2 \mathrm{~h}$. The reaction mixture was diluted with EtOAc, quenched with aqueous sat. sodium bicarbonate, and the aqueous layer extracted with EtOAc. The combined organics were washed with water and brine, dried, concentrated in vacuo, and purified by flash column chromatography $(0-100 \%$ EtOAc in cyclohexane) to give the title compound $(10 \mathrm{mg}$, $20 \%$ ). HRMS (ESI) $m / z$ calcd for $\mathrm{C}_{22} \mathrm{H}_{24} \mathrm{~N}_{7} \mathrm{O}(\mathrm{M}+\mathrm{H}) 402.2037$, found 402.2040. ${ }^{1} \mathrm{H}$ NMR $\left(500 \mathrm{MHz},\left(\mathrm{CD}_{3}\right)_{2} \mathrm{SO}\right) \delta 9.12(\mathrm{~s}, 1 \mathrm{H}), 8.37(\mathrm{~s}, 1 \mathrm{H})$, $8.14(\mathrm{~s}, 1 \mathrm{H}), 7.88(\mathrm{~d}, J=0.9 \mathrm{~Hz}, 1 \mathrm{H}), 7.87-7.79(\mathrm{~m}, 2 \mathrm{H}), 7.24(\mathrm{~d}, J=1.9$ $\mathrm{Hz}, 1 \mathrm{H}), 7.17(\mathrm{dd}, J=8.2,1.9 \mathrm{~Hz}, 1 \mathrm{H}), 6.86(\mathrm{~d}, J=5.4 \mathrm{~Hz}, 1 \mathrm{H}), 3.89(\mathrm{~s}$, $3 \mathrm{H}), 3.87(\mathrm{~s}, 3 \mathrm{H}), 3.84-3.76(\mathrm{~m}, 4 \mathrm{H}), 1.91-1.81(\mathrm{~m}, 4 \mathrm{H})$.

Preparation of Compounds in Scheme 4 (Exemplified by the Preparation of Compounds 34a, 34f, and 38). $N^{8}-I$ sobutyl- $N^{2}-(2-$ methoxy-4-(1-methyl-1H-pyrazol-4-yl)phenyl)pyrido[3,4-d]pyrimidine-2,8-diamine 34a. A mixture of 8-chloro- $N$-(2-methoxy-4(1-methyl-1H-pyrazol-4-yl)phenyl)pyrido[3,4-d]pyrimidin-2-amine
$27 \mathrm{a}^{16}$ (27 mg, $0.074 \mathrm{mmol}$ ) and 2-methylpropan-1-amine (100 $\mu \mathrm{L}, 1.0$ $\mathrm{mmol})$ in NMP $(0.7 \mathrm{~mL})$ was stirred at $130^{\circ} \mathrm{C}$ in a closed cap vial for 5 h. The reaction mixture was quenched with aqueous sat. sodium bicarbonate and extracted with EtOAc. The combined organics were washed with water and brine, dried, and concentrated in vacuo. The residue was purified by flash column chromatography (0-80\% EtOAc in cyclohexane) to give the title compound (19 mg, 63\%). HRMS (ESI) $m / z$ calcd for $\mathrm{C}_{22} \mathrm{H}_{26} \mathrm{~N}_{7} \mathrm{O}(\mathrm{M}+\mathrm{H})$ 404.2193, found 404.2177. ${ }^{1} \mathrm{H}$ NMR $\left(500 \mathrm{MHz},\left(\mathrm{CD}_{3}\right)_{2} \mathrm{SO}\right) \delta 9.16(\mathrm{~s}, 1 \mathrm{H}), 8.43(\mathrm{~s}, 1 \mathrm{H}), 8.19(\mathrm{~d}, J=8.3 \mathrm{~Hz}$, $1 \mathrm{H}), 8.15(\mathrm{~d}, J=0.8 \mathrm{~Hz}, 1 \mathrm{H}), 7.88(\mathrm{~d}, J=0.8 \mathrm{~Hz}, 1 \mathrm{H}), 7.77(\mathrm{~d}, J=5.7$ $\mathrm{Hz}, 1 \mathrm{H}), 7.27(\mathrm{~d}, J=1.9 \mathrm{~Hz}, 1 \mathrm{H}), 7.18(\mathrm{dd}, J=8.2,1.9 \mathrm{~Hz}, 1 \mathrm{H}), 6.88-$ $6.85(\mathrm{~m}, 2 \mathrm{H}), 3.93(\mathrm{~s}, 3 \mathrm{H}), 3.87(\mathrm{~s}, 3 \mathrm{H}), 3.39-3.28(\mathrm{~m}, 2 \mathrm{H}), 2.00$ (hept, $J=6.8 \mathrm{~Hz}, 1 \mathrm{H}), 0.95(\mathrm{~d}, J=6.7 \mathrm{~Hz}, 6 \mathrm{H})$.

8-(Cyclohexylthio)-N-(2-methoxy-4-(1-methyl-1H-pyrazol-4-yl)phenyl)pyrido[3,4-d]pyrimidin-2-amine 34f. A mixture of 8-chloro- $N$ (2-methoxy-4-(1-methyl-1H-pyrazol-4-yl)phenyl)pyrido[3,4-d]pyrimidin-2-amine $27 \mathrm{a}^{16}(26 \mathrm{mg}, 0.071 \mathrm{mmol})$ and potassium carbonate $(15 \mathrm{mg}, 0.11 \mathrm{mmol})$ in DMF $(0.35 \mathrm{~mL})$ was treated with cyclohexanethiol $(12 \mu \mathrm{L}, 0.098 \mathrm{mmol})$ and stirred at rt for $4 \mathrm{~d}$. An additional batch of potassium carbonate $(10 \mathrm{mg}, 0.070 \mathrm{mmol})$ and cyclohexanethiol $(12 \mu \mathrm{L}, 0.098 \mathrm{mmol})$ was added, and the mixture stirred at $50{ }^{\circ} \mathrm{C}$ for $18 \mathrm{~h}$. The reaction was quenched with brine and extracted with EtOAc. The combined organics were washed with water and brine, dried, and concentrated in vacuo. The residue was purified by flash column chromatography (0-80\% EtOAc in cyclohexane) to give the title compound ( $30 \mathrm{mg}, 94 \%$ ). HRMS (ESI) $\mathrm{m} / z$ calcd for $\mathrm{C}_{24} \mathrm{H}_{27} \mathrm{~N}_{6} \mathrm{OS}(\mathrm{M}+\mathrm{H}) 447.1962$, found 447.1948. ${ }^{1} \mathrm{H} \mathrm{NMR}(500 \mathrm{MHz}$, $\left.\left(\mathrm{CD}_{3}\right)_{2} \mathrm{SO}\right) \delta 9.35(\mathrm{~s}, 1 \mathrm{H}), 8.55(\mathrm{br} \mathrm{s}, 1 \mathrm{H}), 8.29(\mathrm{~d}, J=5.4 \mathrm{~Hz}, 1 \mathrm{H}), 8.20$ $(\mathrm{d}, J=0.9 \mathrm{~Hz}, 1 \mathrm{H}), 7.93(\mathrm{~d}, J=0.8 \mathrm{~Hz}, 1 \mathrm{H}), 7.48(\mathrm{~d}, J=5.4 \mathrm{~Hz}, 1 \mathrm{H})$, $7.29(\mathrm{~d}, J=1.9 \mathrm{~Hz}, 1 \mathrm{H}), 7.26(\mathrm{dd}, J=8.2,1.9 \mathrm{~Hz}, 1 \mathrm{H}), 3.96(\mathrm{br} \mathrm{s}, 4 \mathrm{H})$, $3.87(\mathrm{~s}, 3 \mathrm{H}), 2.17-2.05(\mathrm{~m}, 2 \mathrm{H}), 1.82-1.72(\mathrm{~m}, 2 \mathrm{H}), 1.65(\mathrm{~m}, 1 \mathrm{H})$, $1.59-1.40(\mathrm{~m}, 4 \mathrm{H}), 1.35(\mathrm{~m}, 1 \mathrm{H})$.

8-(Cyclopropylmethoxy)-2-(methylthio)pyrido[3,4-d]pyrimidine 36. A suspension of 2-(methylthio)pyrido $[3,4-d]$ pyrimidin- $8(7 H)$-one $35^{16}(502 \mathrm{mg}, 2.60 \mathrm{mmol})$ and silver carbonate $(988 \mathrm{mg}, 3.58 \mathrm{mmol})$ in $\mathrm{CHCl}_{3}(25 \mathrm{~mL})$ was treated with bromomethyl cyclopropane $(310 \mu \mathrm{L}$, $3.19 \mathrm{mmol}$ ) and stirred at $\mathrm{rt}$ for $18 \mathrm{~h}$. The mixture was heated to $60^{\circ} \mathrm{C}$ for $4 \mathrm{~h}$, and an additional batch of bromomethyl cyclopropane $(310 \mu \mathrm{L}$, $3.19 \mathrm{mmol}$ ) was added. The reaction was heated to $60^{\circ} \mathrm{C}$ for $18 \mathrm{~h}$. An additional batch of bromomethyl cyclopropane $(310 \mu \mathrm{L}, 3.19 \mathrm{mmol})$ was added and heated for a further $2 \mathrm{~h}$. $\mathrm{Et}_{3} \mathrm{~N}$ was added $(6 \mathrm{~mL})$, the mixture filtered through Celite $\left(\mathrm{CH}_{2} \mathrm{Cl}_{2}\right)$, and concentrated in vacuo. The residue was purified by flash column chromatography $(0-80 \%$ EtOAc in cyclohexane) to give the title compound $(112 \mathrm{mg}, 17 \%)$ LCMS (ESI) $m / z 248(\mathrm{M}+\mathrm{H}) .{ }^{1} \mathrm{H}$ NMR $\left(500 \mathrm{MHz}, \mathrm{CDCl}_{3}\right) \delta 9.14(\mathrm{~s}$, $1 \mathrm{H}), 8.07(\mathrm{~d}, J=5.6 \mathrm{~Hz}, 1 \mathrm{H}), 7.18(\mathrm{~d}, J=5.6 \mathrm{~Hz}, 1 \mathrm{H}), 4.43(\mathrm{~d}, J=7.0$ $\mathrm{Hz}, 2 \mathrm{H}), 2.74(\mathrm{~s}, 3 \mathrm{H}), 1.48(\mathrm{~m}, 1 \mathrm{H}), 0.73-0.61(\mathrm{~m}, 2 \mathrm{H}), 0.54-0.43(\mathrm{~m}$, $2 \mathrm{H})$.

8-(Cyclopropylmethoxy)-2-(methylsulfonyl)pyrido[3,4-d]pyrimidine 37. A suspension of 8-(cyclopropylmethoxy)-2(methylthio)pyrido[3,4-d]pyrimidine 31 (110 $\mathrm{mg}, 0.445 \mathrm{mmol}$ ) in $\mathrm{CH}_{2} \mathrm{Cl}_{2}(4 \mathrm{~mL})$ was treated with $m$-CPBA $(77 \% \mathrm{w} / \mathrm{w}, 325 \mathrm{mg}, 1.35$ $\mathrm{mmol}$ ) at $0{ }^{\circ} \mathrm{C}$ and then allowed to reach $\mathrm{rt}$ for $18 \mathrm{~h}$. The mixture was quenched with water and extracted with $\mathrm{CH}_{2} \mathrm{Cl}_{2}$. The combined organics were washed with aqueous sat. sodium bicarbonate, dried, and concentrated in vacuo. The residue was purified by flash column chromatography (0-55\% EtOAc in cyclohexane) to give the title compound ( $95 \mathrm{mg}, 77 \%)$. HRMS (ESI) $\mathrm{m} / z$ calcd $\mathrm{C}_{12} \mathrm{H}_{14} \mathrm{~N}_{3} \mathrm{O}_{3} \mathrm{~S}(\mathrm{M}+$ H) 280.0750, found 280.0748. ${ }^{1} \mathrm{H}$ NMR $\left(500 \mathrm{MHz},\left(\mathrm{CD}_{3}\right)_{2} \mathrm{SO}\right) \delta 9.92$ $(\mathrm{s}, 1 \mathrm{H}), 8.44(\mathrm{~d}, J=5.7 \mathrm{~Hz}, 1 \mathrm{H}), 7.72(\mathrm{~d}, J=5.7 \mathrm{~Hz}, 1 \mathrm{H}), 4.43(\mathrm{~d}, J=7.2$ $\mathrm{Hz}, 2 \mathrm{H}), 3.50(\mathrm{~s}, 3 \mathrm{H}), 1.41(\mathrm{~m}, 1 \mathrm{H}), 0.69-0.57(\mathrm{~m}, 2 \mathrm{H}), 0.49-0.40(\mathrm{~m}$, $2 \mathrm{H})$

8-(Cyclopropylmethoxy)-N-(2-methoxy-4-(1-methyl-1H-pyrazol4-yl)phenyl)pyrido[3,4-d]pyrimidin-2-amine 38. A solution of $N$-(2 methoxy-4-(1-methyl-1H-pyrazol-4-yl)phenyl)formamide 26 a $(30 \mathrm{mg}$, $0.13 \mathrm{mmol})$ in THF $(1 \mathrm{~mL})$ was treated with sodium hydride $(60 \% \mathrm{w} / \mathrm{w}$ dispersion in oil, $8 \mathrm{mg}, 0.20 \mathrm{mmol})$ at $0{ }^{\circ} \mathrm{C}$. After stirring for $40 \mathrm{~min}$ at rt, the mixture was cooled to $0{ }^{\circ} \mathrm{C}$, and 8 -(cyclopropylmethoxy)-2(methylsulfonyl)pyrido[3,4- $d$ ] pyrimidine 37 (46 mg, $0.17 \mathrm{mmol}$ ) was added. The reaction was allowed to reach $\mathrm{rt}$ and stirred for $18 \mathrm{~h}$. Sodium 
hydroxide $(2 \mathrm{M}, 1 \mathrm{~mL})$ and $\mathrm{MeOH}(1 \mathrm{~mL})$ were added, and the resulting mixture stirred at $\mathrm{rt}$ for $3 \mathrm{~h}$. The mixture was concentrated in vacuo. The residue was partitioned between EtOAc and water. The aqueous layer was extracted with EtOAc, and the combined organics were washed with water and brine, dried, and concentrated in vacuo. The residue was purified by flash column chromatography $(0-75 \%$ EtOAc in cyclohexane) to give the title compound (27 $\mathrm{mg}, 52 \%)$. HRMS (ESI) $m / z$ calcd for $\mathrm{C}_{22} \mathrm{H}_{23} \mathrm{~N}_{6} \mathrm{O}_{2}(\mathrm{M}+\mathrm{H})$ 403.1877, found 403.1871. ${ }^{1} \mathrm{H} \mathrm{NMR}\left(500 \mathrm{MHz},\left(\mathrm{CD}_{3}\right)_{2} \mathrm{SO}\right) \delta 9.31(\mathrm{~s}, 1 \mathrm{H}), 8.61(\mathrm{~s}, 1 \mathrm{H})$, $8.39(\mathrm{~s}, 1 \mathrm{H}), 8.17(\mathrm{~d}, J=0.8 \mathrm{~Hz}, 1 \mathrm{H}), 7.94-7.84(\mathrm{~m}, 2 \mathrm{H}), 7.35(\mathrm{~d}, J=5.6$ $\mathrm{Hz}, 1 \mathrm{H}), 7.28(\mathrm{~d}, J=1.8 \mathrm{~Hz}, 1 \mathrm{H}), 7.19(\mathrm{dd}, J=8.3,1.8 \mathrm{~Hz}, 1 \mathrm{H}), 4.33(\mathrm{~d}$, $J=6.9 \mathrm{~Hz}, 2 \mathrm{H}), 3.94(\mathrm{~s}, 3 \mathrm{H}), 3.88(\mathrm{~s}, 3 \mathrm{H}), 1.40(\mathrm{~m}, 1 \mathrm{H}), 0.68-0.59(\mathrm{~m}$, $2 \mathrm{H}), 0.49-0.39(\mathrm{~m}, 2 \mathrm{H})$.

Biochemical Assays. MPS1, CDK2, and Aurora A and B counterscreen assays were performed as reported previously. ${ }^{7}$

MSD Assay. $\mathrm{IC}_{50}$ of MPS1 autophosphorylation inhibition at $\mathrm{pTpS}^{33 / 37}$ sites in HCT116 cells was determined by an electrochemiluminescence assay (Meso Scale Discovery, MSD) as described previously. ${ }^{7}$

Cell Viability Assay. Cell proliferation assays were carried out by colorimetric 3-(4,5-dimethylthiazol-2-yl)-2,5-diphenyltetrazolium bromide (MTT) assay (Sigma) in HCT116 cells as described previously. ${ }^{7}$

Crystallization. The kinase domain (residues 519-808) of MPS1 was produced in E. coli and purified as described previously. ${ }^{10 \mathrm{c}}$ For compound 39, apo crystals of MPS1 were grown in PEG300 as previously described ${ }^{7}$ prior to soaking in a fresh solution containing $35 \%$ PEG300, $1 \mathrm{mM}$ inhibitor, and $1 \%$ (v/v) DMSO for $24 \mathrm{~h}$. The crystal was cryo-protected in soak solution supplemented with $22.5 \%$ ethylene glycol prior to flash cooling in liquid nitrogen.

Co-crystals of MPS1 with compound $\mathbf{S 1 1}$ were grown at $18{ }^{\circ} \mathrm{C}$ using the sitting-drop vapor-diffusion method. The crystallization drops were composed of $2 \mu \mathrm{L}$ of protein/ligand solution $(8.9 \mathrm{mg} / \mathrm{mL}$ protein and 5 mM S11) and $2 \mu \mathrm{L}$ of reservoir solution placed over $200 \mu \mathrm{L}$ of reservoir solution of $18-26 \%(\mathrm{w} / \mathrm{v})$ PEG3350, 0.1 M bis-Tris propane $\mathrm{pH} 7.5$, $0.1 \mathrm{M} \mathrm{MgCl}_{2}$, and $0.1 \mathrm{M}$ sodium formate in 48 -well plates. Co-crystals typically grew in 12-16 h. Crystals of MPS1 with S11 were transferred to backsoaking solutions containing reservoir solution also containing $200 \mathrm{mM}$ of inhibitor and up to $20 \%$ (v/v) DMSO and incubated at 18 ${ }^{\circ} \mathrm{C}$ for $24-48 \mathrm{~h}$. Crystals were cryo-protected with paratone-N oil prior to flash cooling in liquid nitrogen.

Co-crystals of MPS1 with compound 34e were grown at $18{ }^{\circ} \mathrm{C}$ using the sitting-drop vapor-diffusion method. The crystallization drops were composed of $2 \mu \mathrm{L}$ of protein/ligand solution $(11.4 \mathrm{mg} / \mathrm{mL}$ protein and $2 \mathrm{mM} 34 \mathrm{e}$ ) with $20 \%$ (w/v) PEG3350, $0.1 \mathrm{M}$ bis-Tris propane $\mathrm{pH} 7.5$, and $0.2 \mathrm{M}$ sodium formate. Crystals were cryo-protected with paratone$\mathrm{N}$ oil prior to flash cooling in liquid nitrogen.

Data Collection, Structure Solution, and Refinement. X-ray diffraction data were collected at $100 \mathrm{~K}$ at Diamond Light Source (Oxfordshire, U.K.) or in-house on a Rigaku FRX with Pilatus $300 \mathrm{~K}$ detector. Data were integrated with $\mathrm{XDS}^{24}$ or MOSFLM (S11 data set only). ${ }^{25}$ All data were imported to MTZ format with POINTLESS, ${ }^{26}$ then scaled and merged with AIMLESS ${ }^{26}$ in the CCP4 suite. ${ }^{25}$ The structures were solved by molecular replacement with PHASER, ${ }^{27}$ with the PDB structure $4 \mathrm{C}^{7} \mathrm{~J}^{7}$ as the search model after removal of all nonprotein atoms. Structures were refined in iterative cycles of model building with $\mathrm{COOT}^{28}$ and refinement with BUSTER. ${ }^{29}$ TLS groups were selected with PHENIX phenix.find_tls groups. ${ }^{30}$ Ligand restraints were generated with GRADE ${ }^{31}$ and $\overline{M O G U L}{ }^{32}$ The final structure quality was checked with MOLPROBITY. ${ }^{33}$ The data collection and refinement statistics are presented in Table S7.

Microsomal Metabolism. Microsomal turnover was carried out in male CD1 mice, female Sprague-Dawley rats, and pooled human liver microsomes obtained from Tebu-Bio (Peterborough, U.K.) following $30 \mathrm{~min}$ incubation of $10 \mu \mathrm{M}$ compound in $1 \mathrm{mg} / \mathrm{mL}$ microsomal protein, $3 \mathrm{mmol} / \mathrm{L} \mathrm{MgCl}_{2}, 1 \mathrm{mmol} / \mathrm{L} \mathrm{NADPH}, 2.5 \mathrm{mmol} / \mathrm{L}$, UDPglucuronic acid, and $10 \mathrm{mmol} / \mathrm{L}$ phosphate buffer ( $\mathrm{pH}$ 7.4) (all purchased from Sigma-Aldrich, Gillingham, U.K). Reactions, at $37^{\circ} \mathrm{C}$, were started by addition of the test compound and were terminated at 0 and $30 \mathrm{~min}$ by the addition of 3 volumes of ice-cold methanol containing internal standard. Samples were centrifuged at $2800 \mathrm{~g}$ for $30 \mathrm{~min}$ at $4{ }^{\circ} \mathrm{C}$ and the supernatants analyzed. Control incubations were prepared as above with omission of cofactors. Compound measurements were performed by LCMS on an Agilent quadrupole time-of-flight instrument (Agilent 6510) following separation with a 6 min gradient of $10 \mathrm{mM}$ ammonium acetate in methanol on a $50 \times 2.1 \mathrm{~mm} 2.6 \mu \mathrm{m}$ particles $\mathrm{C} 18$ column (Kinetex Phenomenex). For metabolite identification, the gradient was extended to $20 \mathrm{~min}$, and MS/MS carried out with fragment elucidation for ions of interest.

Pharmacokinetic Studies. All in vivo studies were performed in accordance with U.K. Home Office regulations, ICR ethical review processes, and U.K. National Cancer Research Institute guidelines. ${ }^{34}$ Female Balb/C mice and Sprague-Dawley rats were obtained from Charles River (Margate, U.K.). Animals were adapted to laboratory conditions for at least 1 week prior to dosing and were allowed food and water ad libitum. Compounds were administered iv or po (mouse: 0.1 $\mathrm{mL} / 10 \mathrm{~g}$ in $10 \%$ DMSO, $5 \%$ tween 20 in saline, rat: $0.05 \mathrm{~mL} / 10 \mathrm{~g}$ in $10 \%$ DMSO, $5 \%$ tween 20 in saline). Blood samples were collected from the tail vein $(20 \mu \mathrm{L})$ at 8 time points over the 24 h post dose and spotted on Whatman B cards together with a standard curve and quality controls spiked in control blood. Cards were allowed to dry at rt for at least $6 \mathrm{~h}$. Cards were punched, and $6 \mathrm{~mm}$ discs were extracted with $200 \mu \mathrm{L}$ methanol containing $500 \mathrm{nM}$ olomoucine as an internal standard. Following centrifugation, extracts were analyzed by multiple reaction monitoring of precursor and product ions by ESI-LCMS/MS on a QTRAP 4000 (ABSciex) following separation as above. Quantitation was carried out with an external calibration (8 points ranging from $1 \mathrm{nM}$ to $25 \mu \mathrm{M}$ ). Quality controls were included (3 concentrations) at the beginning and the end of the analytical run and were within $20 \%$ of nominal concentrations.

Pharmacokinetic parameters were derived from noncompartmental analysis WiniNONlin (model 200 and 201) Pharsight version.

In Vivo Proof-of-Concept Studies. Animals (6-8 week old female $\mathrm{NCr}$ athymic mice) were supplied by a commercial breeder and fed sterilized food and water ad libitum.

PK/PD Study. Three million HCT116 human colorectal carcinoma cells were injected s.c. bilaterally into the flanks. Dosing commenced when tumors reached a mean diameter of $8-10 \mathrm{~mm}$ (day 14). Animals ( $n=6$ per group) were dosed twice daily with compound $34 \mathrm{~h}(100 \mathrm{mg} /$ $\mathrm{kg}$ po) or vehicle ( $10 \% \mathrm{DMSO}, 5 \%$ Tween $20,85 \%$ saline) over 3 days ( 6 doses), and groups of three were culled at 2 or $6 \mathrm{~h}$ after the final dose. Heparinized plasma and tumor samples were collected and snap frozen for pharmacokinetic (PK) and pharmacodynamic (PD) biomarker analysis.

PD Assays. For PD analysis, frozen tumor samples were homogenized in RIPA lysis buffer $(150 \mathrm{mM} \mathrm{NaCl}, 50 \mathrm{mM}$ Tris $\mathrm{pH}$ 7.5, 1 mM EDTA pH 8.0, 1\% NP40, 1\% sodium deoxycholate, $1 \%$ sodium dodecyl sulfate, and supplemented with protease and phosphatase inhibitors), sonicated, and centrifuged to clear the debris. Protein concentrations of the supernatants were measured, and $5 \mu \mathrm{g}$ protein for each sample was loaded onto LDS-PAGE (Life technologies). Proteins were separated, transferred to nitrocellulose membrane, and probed with phospho-histone H3 (Millipore), totalhistone H3 (Abcam), cleaved-PARP (Cell Signaling), and GAPDH (Millipore) antibodies. Blots were quantified using ImageJ and analyzed with Graphpad Prism.

\section{ASSOCIATED CONTENT}

\section{Supporting Information}

The Supporting Information is available free of charge on the ACS Publications website at DOI: 10.1021/acs.jmedchem.5b01811.

\section{Additional data (CSV)}

Experimental procedures and analytical data for final compounds 24b, 24c, 28c, 28d, 28e, 33b, 34b-e, 34g, 34h, intermediates and formamides. Aurora A and B inhibition data available for all compounds. CYP and hERG activity as well as kinase selectivity profiling of $\mathbf{3 4 h}$. 
Crystallographic analysis of compounds 15b, 24b, 24c, 34e, 39 bound to MPS1 (PDF)

\section{Accession Codes}

Atomic coordinates and structure factors for compounds $\mathbf{1}, \mathbf{1 5 b}$, 24b, 24c, 34e and 39 can be accessed using PBD codes 4C4J, 5EI6, 5EI2, 5EI8, 5EH0, 5EHY, respectively.

\section{AUTHOR INFORMATION}

\section{Corresponding Author}

*E-mail: swen.hoelder@icr.ac.uk. Phone: +44 (0)2087224353.

\section{Present Address}

"SBA School of Science and Engineering, Lahore University of Management Sciences, D.H.A., Lahore 54792, Pakistan.

Notes

The authors declare no competing financial interest.

\section{ACKNOWLEDGMENTS}

This work was supported by Cancer Research U.K. [grant number C309/A11566]. We also acknowledge the Cancer Research Technology Pioneer Fund and Sixth Element Capital for funding (to P.I.) and NHS funding to the NIHR Biomedical Research Centre. S.L. is also supported by Breakthrough Breast Cancer (recently merged with Breast Cancer Campaign forming Breast Cancer Now). We thank the staff of DIAMOND Light Source for their support during data collection. We thank Dr. Amin Mirza, Dr. Maggie Liu, and Mr. Meirion Richards for their help with LC, NMR, and mass spectrometry.

\section{ABBREVIATIONS USED}

CDK2, cyclin-dependent kinase 2; Cl, clearance; hERG, human ether-à-go-go-related gene; HLM, human liver microsomes; JNK1, $c$-Jun $\mathrm{N}$-terminal kinase 1; JNK2, $c$-Jun $\mathrm{N}$-terminal kinase 2; L.E., ligand efficiency; L.L.E, lipophilic ligand efficiency; LRRK, leucine-rich repeat kinase; MLM, mouse liver microsomes; MPS1, monopolar spindle kinase 1; MSD, Meso Scale Discovery; MTT, 3-(4,5-dimethylthiazol-2-yl)-2,5-diphenyltetrazolium bromide; PARP, poly $\mathrm{ADP}$ ribose polymerase; PLK1, polo-like kinase 1; PTEN, phosphatase and tensin homologue; SAC, spindle assembly checkpoint; RLM, rat liver microsomes; TGI, tumor growth inhibition; $V_{s s}$, volume of distribution

\section{REFERENCES}

(1) (a) Jackson, J. R.; Patrick, D. R.; Dar, M. M.; Huang, P. S. Targeted anti-mitotic therapies: can we improve on tubulin agents? Nat. Rev. Cancer 2007, 7, 107-117. (b) Wood, K. W.; Cornwell, W. D.; Jackson, J. R. Past and future of the mitotic spindle as an oncology target. Curr. Opin. Pharmacol. 2001, 1, 370-377. (c) Chan, K. S.; Koh, C. G.; Li, H. Y. Mitosis-targeted anti-cancer therapies: where they stand. Cell Death Dis. 2012, 3, e411.

(2) (a) Hardwick, K. G. The spindle checkpoint. Trends Genet. 1998, 14, 1-4. (b) Mills, G. B.; Schmandt, R.; McGill, M.; Amendola, A.; Hill, M.; Jacobs, K.; May, C.; Rodricks, A. M.; Campbell, S.; Hogg, D. Expression of TTK, a novel human protein kinase, is associated with cell proliferation. J. Biol. Chem. 1992, 267, 16000-16006. (c) Lauze, E.; Stoelcker, B.; Luca, F. C.; Weiss, E.; Schutz, A. R.; Winey, M. Yeast spindle pole body duplication gene MPS1 encodes an essential dual specificity protein kinase. EMBO J. 1995, 14, 1655-1663. (d) Musacchio, A.; Salmon, E. D. The spindle-assembly checkpoint in space and time. Nat. Rev. Mol. Cell Biol. 2007, 8, 379-393.

(3) (a) Daniel, J.; Coulter, J.; Woo, J.-H.; Wilsbach, K.; Gabrielson, E. High levels of the Mps1 checkpoint protein are protective of aneuploidy in breast cancer cells. Proc. Natl. Acad. Sci. U. S. A. 2011, 108, 5384-
5389. (b) Brough, R.; Frankum, J. R.; Sims, D.; MacKay, A.; MendesPereira, A. M.; Bajrami, I.; Costa-Cabral, S.; Rafiq, R.; Ahmad, A. S.; Cerone, M. A.; Natrajan, R.; Sharpe, R.; Shiu, K.-K.; Wetterskog, D.; Dedes, K. J.; Lambros, M. B.; Rawjee, T.; Linardopoulos, S.; Reis-Filho, J. S.; Turner, N. C.; Lord, C. J.; Ashworth, A. Functional Viability Profiles of Breast Cancer. Cancer Discovery 2011, 1, 260-273. (c) Gordon, D. J.; Resio, B.; Pellman, D. Causes and consequences of aneuploidy in cancer. Nat. Rev. Genet. 2012, 13, 189-203.

(4) (a) Yuan, B.; Xu, Y.; Woo, J.-H.; Wang, Y.; Bae, Y. K.; Yoon, D.-S.; Wersto, R. P.; Tully, E.; Wilsbach, K.; Gabrielson, E. Increased Expression of Mitotic Checkpoint Genes in Breast Cancer Cells with Chromosomal Instability. Clin. Cancer Res. 2006, 12, 405-410. (b) Mizukami, Y.; Kono, K.; Daigo, Y.; Takano, A.; Tsunoda, T.; Kawaguchi, Y.; Nakamura, Y.; Fujii, H. Detection of novel cancer-testis antigen-specific T-cell responses in TIL, regional lymph nodes, and PBL in patients with esophageal squamous cell carcinoma. Cancer Sci. 2008, 99, 1448-1454. (c) Salvatore, G.; Nappi, T. C.; Salerno, P.; Jiang, Y.; Garbi, C.; Ugolini, C.; Miccoli, P.; Basolo, F.; Castellone, M. D.; Cirafici, A. M.; Melillo, R. M.; Fusco, A.; Bittner, M. L.; Santoro, M. A Cell Proliferation and Chromosomal Instability Signature in Anaplastic Thyroid Carcinoma. Cancer Res. 2007, 67, 10148-10158. (d) Thykjaer, T.; Workman, C.; Kruhoffer, M.; Demtroder, K.; Wolf, H.; Andersen, L. D.; Frederiksen, C. M.; Knudsen, S.; Orntoft, T. F. Identification of gene expression patterns in superficial and invasive human bladder cancer. Cancer Res. 2001, 61, 2492-2499.

(5) (a) Tannous, B. A.; Kerami, M.; Van der Stoop, P. M.; Kwiatkowski, N.; Wang, J.; Zhou, W.; Kessler, A. F.; Lewandrowski, G.; Hiddingh, L.; Sol, N.; Lagerweij, T.; Wedekind, L.; Niers, J. M.; Barazas, M.; Nilsson, R. J. A.; Geerts, D.; De Witt Hamer, P. C.; Hagemann, C.; Vandertop, W. P.; Van Tellingen, O.; Noske, D. P.; Gray, N. S.; Würdinger, T. Effects of the Selective MPS1 Inhibitor MPS1-IN-3 on Glioblastoma Sensitivity to Antimitotic Drugs. J. Nat. Canc. Inst. 2013, 105, 1322-1331. (b) Slee, R. B.; Grimes, B. R.; Bansal, R.; Gore, J.; Blackburn, C.; Brown, L.; Gasaway, R.; Jeong, J.; Victorino, J.; March, K. L.; Colombo, R.; Herbert, B. S.; Korc, M. Selective inhibition of pancreatic ductal adenocarcinoma cell growth by the mitotic MPS1 kinase inhibitor NMS-P715. Mol. Cancer Ther. 2014, 13, 307-315.

(6) Aarts, M.; Linardopoulos, S.; Turner, N. C. Tumour selective targeting of cell cycle kinases for cancer treatment. Curr. Opin. Pharmacol. 2013, 13, 529-535.

(7) Naud, S.; Westwood, I. M.; Faisal, A.; Sheldrake, P.; Bavetsias, V.; Atrash, B.; Cheung, K.-M. J.; Liu, M.; Hayes, A.; Schmitt, J.; Wood, A.; Choi, V.; Boxall, K.; Mak, G.; Gurden, M.; Valenti, M.; de Haven Brandon, A.; Henley, A.; Baker, R.; McAndrew, C.; Matijssen, B.; Burke, R.; Hoelder, S.; Eccles, S. A.; Raynaud, F. I.; Linardopoulos, S.; van Montfort, R. L. M.; Blagg, J. Structure-Based Design of Orally Bioavailable $1 H$-Pyrrolo[3,2-c]pyridine Inhibitors of Mitotic Kinase Monopolar Spindle 1 (MPS1). J. Med. Chem. 2013, 56, 10045-10065.

(8) (a) Kusakabe, K.-i.; Ide, N.; Daigo, Y.; Itoh, T.; Yamamoto, T.; Hashizume, H.; Nozu, K.; Yoshida, H.; Tadano, G.; Tagashira, S.; Higashino, K.; Okano, Y.; Sato, Y.; Inoue, M.; Iguchi, M.; Kanazawa, T.; Ishioka, Y.; Dohi, K.; Kido, Y.; Sakamoto, S.; Ando, S.; Maeda, M.; Higaki, M.; Baba, Y.; Nakamura, Y. Discovery of Imidazo[1,2b]pyridazine Derivatives: Selective and Orally Available Mps1 (TTK) Kinase Inhibitors Exhibiting Remarkable Antiproliferative Activity. J. Med. Chem. 2015, 58, 1760-1775. (b) Laufer, R.; Ng, G.; Liu, Y.; Patel, N. K. B.; Edwards, L. G.; Lang, Y.; Li, S.-W.; Feher, M.; Awrey, D. E.; Leung, G.; Beletskaya, I.; Plotnikova, O.; Mason, J. M.; Hodgson, R.; Wei, X.; Mao, G.; Luo, X.; Huang, P.; Green, E.; Kiarash, R.; Lin, D. C.C.; Harris-Brandts, M.; Ban, F.; Nadeem, V.; Mak, T. W.; Pan, G. J.; Qiu, W.; Chirgadze, N. Y.; Pauls, H. W. Discovery of inhibitors of the mitotic kinase TTK based on $\mathrm{N}$-(3-(3-sulfamoylphenyl)-1H-indazol-5-yl)acetamides and carboxamides. Bioorg. Med. Chem. 2014, 22, 49684997. (c) Tardif, K. D.; Rogers, A.; Cassiano, J.; Roth, B. L.; Cimbora, D. M.; McKinnon, R.; Peterson, A.; Douce, T. B.; Robinson, R.; Dorweiler, I.; Davis, T.; Hess, M. A.; Ostanin, K.; Papac, D. I.; Baichwal, V.; McAlexander, I.; Willardsen, J. A.; Saunders, M.; Christophe, H.; Kumar, D. V.; Wettstein, D. A.; Carlson, R. O.; Williams, B. L. Characterization of the Cellular and Antitumor Effects of MPI-0479605, a Small- 
Molecule Inhibitor of the Mitotic Kinase Mps1. Mol. Cancer Ther. 2011, $10,2267-2275$.

(9) (a) Martinez, R.; Blasina, A.; Hallin, J. F.; Hu, W.; Rymer, I.; Fan, J.; Hoffman, R. L.; Murphy, S.; Marx, M.; Yanochko, G.; Trajkovic, D.; Dinh, D.; Timofeevski, S.; Zhu, Z.; Sun, P.; Lappin, P. B.; Murray, B. W. Mitotic Checkpoint Kinase Mps1 Has a Role in Normal Physiology which Impacts Clinical Utility. PLoS One 2015, 10, e0138616. (b) Wengner, A. M.; Siemeister, G. Combination of a imidazopyridazine derivative and a mitotic agent for the treatment of cancer. Patent WO2014198776A1, December 18, 2014. (c) Wengner, A. M.; Siemeister, G. Combinations for the treatment of cancer comprising a mps-1 kinase inhibitor and a mitotic inhibitor. Patent WO2014198645, December 18, 2014. (d) Maia, A. R. R.; de Man, J.; Boon, U.; Janssen, A.; Song, J.-Y.; Omerzu, M.; Sterrenburg, J. G.; Prinsen, M. B. W.; Willemsen-Seegers, N.; de Roos, J. A. D. M.; van Doornmalen, A. M.; Uitdehaag, J. C. M.; Kops, G. J. P. L.; Jonkers, J.; Buijsman, R. C.; Zaman, G. J. R.; Medema, R. H. Inhibition of the spindle assembly checkpoint kinase TTK enhances the efficacy of docetaxel in a triple-negative breast cancer model. Ann. Oncol. 2015, 26, 2180.

(10) (a) Kusakabe, K.-i.; Ide, N.; Daigo, Y.; Tachibana, Y.; Itoh, T.; Yamamoto, T.; Hashizume, H.; Hato, Y.; Higashino, K.; Okano, Y.; Sato, Y.; Inoue, M.; Iguchi, M.; Kanazawa, T.; Ishioka, Y.; Dohi, K.; Kido, Y.; Sakamoto, S.; Yasuo, K.; Maeda, M.; Higaki, M.; Ueda, K.; Yoshizawa, H.; Baba, Y.; Shiota, T.; Murai, H.; Nakamura, Y. Indazole-Based Potent and Cell-Active Mps1 Kinase Inhibitors: Rational Design from PanKinase Inhibitor Anthrapyrazolone (SP600125). J. Med. Chem. 2013, 56, 4343-4356. (b) Hewitt, L.; Tighe, A.; Santaguida, S.; White, A. M.; Jones, C. D.; Musacchio, A.; Green, S.; Taylor, S. S. Sustained Mps1 activity is required in mitosis to recruit O-Mad2 to the Mad1-C-Mad2 core complex. J. Cell Biol. 2010, 190, 25-34. (c) Langdon, S. R.; Westwood, I. M.; van Montfort, R. L. M.; Brown, N.; Blagg, J. ScaffoldFocused Virtual Screening: Prospective Application to the Discovery of TTK Inhibitors. J. Chem. Inf. Model. 2013, 53, 1100-1112. (d) Chu, M. L. H.; Chavas, L. M. G.; Douglas, K. T.; Eyers, P. A.; Tabernero, L. Crystal Structure of the Catalytic Domain of the Mitotic Checkpoint Kinase Mps1 in Complex with SP600125. J. Biol. Chem. 2008, 283, 21495-21500. (e) Kwiatkowski, N.; Jelluma, N.; Filippakopoulos, P.; Soundararajan, M.; Manak, M. S.; Kwon, M.; Choi, H. G.; Sim, T.; Deveraux, Q. L.; Rottmann, S.; Pellman, D.; Shah, J. V.; Kops, G. J. P. L.; Knapp, S.; Gray, N. S. Small-molecule kinase inhibitors provide insight into Mps1 cell cycle function. Nat. Chem. Biol. 2010, 6, 359-368. (f) Santaguida, S.; Tighe, A.; D’Alise, A. M.; Taylor, S. S.; Musacchio, A. Dissecting the role of MPS1 in chromosome biorientation and the spindle checkpoint through the small molecule inhibitor reversine. J. Cell Biol. 2010, 190, 73-87. (g) Kusakabe, K.-i.; Ide, N.; Daigo, Y.; Itoh, T.; Yamamoto, T.; Kojima, E.; Mitsuoka, Y.; Tadano, G.; Tagashira, S.; Higashino, K.; Okano, Y.; Sato, Y.; Inoue, M.; Iguchi, M.; Kanazawa, T.; Ishioka, Y.; Dohi, K.; Kido, Y.; Sakamoto, S.; Ando, S.; Maeda, M.; Higaki, M.; Yoshizawa, H.; Murai, H.; Nakamura, Y. A unique hinge binder of extremely selective aminopyridine-based Mps1 (TTK) kinase inhibitors with cellular activity. Bioorg. Med. Chem. 2015, 23, 22472260.

(11) (a) Caldarelli, M.; Angiolini, M.; Disingrini, T.; Donati, D.; Guanci, M.; Nuvoloni, S.; Posteri, H.; Quartieri, F.; Silvagni, M.; Colombo, R. Synthesis and SAR of new pyrazolo[4,3- $h]$ quinazoline-3carboxamide derivatives as potent and selective MPS1 kinase inhibitors. Bioorg. Med. Chem. Lett. 2011, 21, 4507-4511. (b) Colombo, R; Caldarelli, M.; Mennecozzi, M.; Giorgini, M. L.; Sola, F.; Cappella, P.; Perrera, C.; Depaolini, S. R.; Rusconi, L.; Cucchi, U.; Avanzi, N.; Bertrand, J. A.; Bossi, R. T.; Pesenti, E.; Galvani, A.; Isacchi, A.; Colotta, F.; Donati, D.; Moll, J. Targeting the Mitotic Checkpoint for Cancer Therapy with NMS-P715, an Inhibitor of MPS1 Kinase. Cancer Res. 2010, 70, 10255-10264.

(12) Liu, Y.; Lang, Y.; Patel, N. K.; Ng, G.; Laufer, R.; Li, S.-W.; Edwards, L.; Forrest, B.; Sampson, P. B.; Feher, M.; Ban, F.; Awrey, D. E.; Beletskaya, I.; Mao, G.; Hodgson, R.; Plotnikova, O.; Qiu, W.; Chirgadze, N. Y.; Mason, J. M.; Wei, X.; Lin, D. C.-C.; Che, Y.; Kiarash, R.; Madeira, B.; Fletcher, G. C.; Mak, T. W.; Bray, M. R.; Pauls, H. W. The discovery of orally bioavailable tyrosine threonine kinase (TTK) inhibitors: 3-(4-(heterocyclyl)phenyl)-1H-indazole-5-carboxamides as anticancer agents. J. Med. Chem. 2015, 58, 3366-3392.

(13) Kusakabe, K.-i.; Ide, N.; Daigo, Y.; Itoh, T.; Higashino, K.; Okano, Y.; Tadano, G.; Tachibana, Y.; Sato, Y.; Inoue, M.; Wada, T.; Iguchi, M.; Kanazawa, T.; Ishioka, Y.; Dohi, K.; Tagashira, S.; Kido, Y.; Sakamoto, S.; Yasuo, K.; Maeda, M.; Yamamoto, T.; Higaki, M.; Endoh, T.; Ueda, K.; Shiota, T.; Murai, H.; Nakamura, Y. Diaminopyridine-Based Potent and Selective Mps1 Kinase Inhibitors Binding to an Unusual FlippedPeptide Conformation. ACS Med. Chem. Lett. 2012, 3, 560-564.

(14) The inherent acid lability of the Boc group prevented further development (further details will be published in due course).

(15) Hopkins, A. L.; Groom, C. R.; Alex, A. Ligand efficiency: a useful metric for lead selection. Drug Discovery Today 2004, 9, 430-431.

(16) Innocenti, P.; Woodward, H.; O’Fee, L.; Hoelder, S. Expanding the scope of fused pyrimidines as kinase inhibitor scaffolds: synthesis and modification of pyrido $[3,4-d]$ pyrimidines. Org. Biomol. Chem. 2015, 13, 893-904.

(17) Bavetsias, V.; Atrash, B.; Naud, S. G. A.; Sheldrake, P. W.; Blagg, J. Preparation of pyrrolopyridinamine derivatives as Mps1 inhibitors. Patent WO2012123745A1, September 20, 2012.

(18) Dave, C. G.; Shah, P. R.; Desai, V. B.; Srinivasan, S. Pyridopyrimidines. Part I. Synthesis and biological activity of 2thiopyrido[2,3-d]pyrimidin-4(3H)]ones. Indian J. Chem., Sect. B 1982, $21 B, 750-752$.

(19) Lovering, F.; Bikker, J.; Humblet, C. Escape from Flatland: Increasing Saturation as an Approach to Improving Clinical Success. J. Med. Chem. 2009, 52, 6752-6756.

(20) Copeland, R. A. Evaluation of Enzyme Inhibitors in Drug Discovery; Wiley: Hoboken, NJ, 2005; Vol. 46.

(21) Pesson, M.; Chabassier, S. Nitriles and amide-oximes of 8-alkyl-5oxo 35,8-dihydro[2,3-d] pyrido-6-pyrimidinecarboxylic acids. C. R. Seances Acad. Sci., Ser. C 1974, 279, 413-415.

(22) (a) Ajiro, K.; Nishimoto, T. Specific site of histone H3 phosphorylation related to the maintenance of premature chromosome condensation. Evidence for catalytically induced interchange of the subunits. J. Biol. Chem. 1985, 260, 15379-15381. (b) Juan, G.; Traganos, F.; James, W. M.; Ray, J. M.; Roberge, M.; Sauve, D. M.; Anderson, H.; Darzynkiewicz, Z. Histone H3 phosphorylation and expression of cyclins A and B1 measured in individual cells during their progression through G2 and mitosis. Cytometry 1998, 32, 71-77.

(23) Honold, K.; Paul, J.; Roeschlaub, C.; Schaefer, W.; Scheiblich, S.; Von, H., Thomas; Whittle, A. Preparation of 7H-pyrido[3,4-d]pyrimidin-8-ones as protein kinase inhibitors. Patent WO2007088014A1, August 9, 2007.

(24) Kabsch, W. Software XDS for image rotation, recognition and crystal symmetry assignment. Acta Crystallogr., Sect. D: Biol. Crystallogr. 2010, 66, 125-132.

(25) Winn, M. D.; Ballard, C. C.; Cowtan, K. D.; Dodson, E. J.; Emsley, P.; Evans, P. R.; Keegan, R. M.; Krissinel, E. B.; Leslie, A. G. W.; McCoy, A.; McNicholas, S. J.; Murshudov, G. N.; Pannu, N. S.; Potterton, E. A.; Powell, H. R.; Read, R. J.; Vagin, A.; Wilson, K. S. Overview of the CCP4 suite and current developments. Acta Crystallogr., Sect. D: Biol. Crystallogr. 2011, 67, 235-242.

(26) Evans, P. Scaling and assessment of data quality. Acta Crystallogr., Sect. D: Biol. Crystallogr. 2006, 62, 72-82.

(27) McCoy, A. J.; Grosse-Kunstleve, R. W.; Adams, P. D.; Winn, M. D.; Storoni, L. C.; Read, R. J. Phaser crystallographic software. J. Appl. Crystallogr. 2007, 40, 658-674.

(28) Emsley, P.; Cowtan, K. Coot: model-building tools for molecular graphics. Acta Crystallogr., Sect. D: Biol. Crystallogr. 2004, 60, 21262132.

(29) Bricogne, G.; Blanc, E.; Brandl, M.; Flensburg, C.; Keller, P.; Paciorek, W.; Roversi, P.; Sharff, A.; Smart, O. S.; Vonrhein, C.; Womack, T. O. BUSTER, version 2.11.4; Global Phasing Ltd.: Cambridge, U.K., 2012.

(30) Adams, P. D.; Afonine, P. V.; Bunkóczi, G.; Chen, V. B.; Davis, I. W.; Echols, N.; Headd, J. J.; Hung, L.-W.; Kapral, G. J.; GrosseKunstleve, R. W.; McCoy, A. J.; Moriarty, N. W.; Oeffner, R.; Read, R. J.; Richardson, D. C.; Richardson, J. S.; Terwilliger, T. C.; Zwart, P. H. 
PHENIX: a comprehensive Python-based system for macromolecular structure solution. Acta Crystallogr., Sect. D: Biol. Crystallogr. 2010, 66, 213-221.

(31) Smart, O. S.; Womack, T. O.; Sharff, A.; Flensburg, C.; Keller, P.; Paciorek, W.; Vonrhein, C.; Bricogne, G. Grade, version 1.2.1; Global Phasing Ltd.: Cambridge, U.K., 2012.

(32) Bruno, I. J.; Cole, J. C.; Lommerse, J. P. M.; Rowland, R. S.; Taylor, R; Verdonk, M. L. Isostar: a library of information about nonbonded interactions. J. Comput.-Aided Mol. Des. 1997, 11, 525-537. (33) Davis, I. W.; Leaver-Fay, A.; Chen, V. B.; Block, J. N.; Kapral, G. J.; Wang, X.; Murray, L. W.; Arendall, W. B.; Snoeyink, J.; Richardson, J. S.; Richardson, D. C. MolProbity: all-atom contacts and structure validation for proteins and nucleic acids. Nucleic Acids Res. 2007, 35, W375-W383.

(34) Workman, P.; Aboagye, E. O.; Balkwill, F.; Balmain, A.; Bruder, G.; Chaplin, D. J.; Double, J. A.; Everitt, J.; Farningham, D. A. H.; Glennie, M. J.; Kelland, L. R.; Robinson, V.; Stratford, I. J.; Tozer, G. M.; Watson, S.; Wedge, S. R.; Eccles, S. A. Guidelines for the welfare and use of animals in cancer research. Br. J. Cancer 2010, 102, 1555-1577. 